\title{
Generic limits in the Rytidosperma (Danthonieae, Poaceae) complex
}

\author{
H. Peter Linder and G. Anthony Verboom
}

\begin{abstract}
Linder, H. Peter and Verboom, G. Anthony (Bolus Herbarium, University of Cape Town, Rondebosch 7700, South Africa) 1996. Generic limits in the Rytidosperma (Danthonieae, Poaceae) complex. Telopea 6(4): 597-627. The generic limits of the Australasian danthonioid grasses are re-assessed using morphological and anatomical data from virtually all danthonioid species. These data, encoded in the DELTA system, were analysed using parsimony. The position of these genera within the Poaceae, and the broad structure of the relationships between them, has been assessed previously using both embryological information and molecular analyses. The results of the present study support the recognition of Plinthanthesis, Notochloe and Schismus, as well as corroborating the distinction between Danthonia and Rytidosperma. Rytidosperma sensu Zotov is segregated into three genera: Rytidosperma s.s. with 35 species, which includes Monostachya, Erythranthera and Pyrrhanthera; Notodanthonia with 28 species; and two new genera, Thonandia (5 species) and Joycea ( 3 species). These genera are characterised morphologically and ecologically, and the species included in each genus listed. The relevant new combinations are made.
\end{abstract}

\section{Introduction}

The last comprehensive, critical taxonomic study of the Australian danthonioids was by Vickery (1956), whose exemplary account of the species boundaries and nomenclature laid a solid foundation for further work. Vickery placed all species in a very broadly defined Danthonia, a concept which was current at that time. Within a few years, however, the dismantling of this large, unwieldy genus had begun. Zotov (1963) initiated this process by segregating the New Zealand species into four genera: Chionochloa, Notodanthonia, Erythranthera, and Pyrrhanthera. During the next decade, Conert, following the results of De Wet $(1956,1960)$, removed most of the African species into separate genera: Dregeochloa (Conert 1966), Karroochloa (Conert \& Türpe 1969), Merxmuellera (Conert 1970, 1971), and Pseudopentameris (Conert 1971). The Australasian segregation was finally completed when Blake (1972) recognised Notodanthonia, Plinthanthesis and Monachather, thus leaving no Danthonia species native to Australasia and southern Africa. Blake did not make the relevant combinations for Notodanthonia: that was eventually done by Connor and Edgar (1979). Nicora (1973) completed the redelimitation of Danthonia by removing six South American species from Danthonia to Rytidosperma. This reduced Danthonia from a ubiquitous genus of some 150 species, to a small genus of ca. 23 species, ranging from South America (9 species), through North America ( 8 species) to Europe ( 3 species) and North-East Africa (2 species) and Asia (2 species). Subsequently, Connor and Edgar (1979) transferred all the Australasian species of Notodanthonia to Rytidosperma.

This fragmentation of Danthonia has not gone unchallenged. The separation of Chionochloa has been generally accepted (Blake 1972, Conert 1975, Connor 1991, Jacobs 1994): Chionochloa is sharply discontinuous from the rest of Danthonia s.l. by its bizarre leaf anatomy, shaggy three-rowed lemma indumentum, and the shape of the paleas (Linder in prep.). Although the genus is clearly danthonioid, it is not closely related to the Rytidosperma-Danthonia clade (Linder in prep.). There is one 
species of Chionochloa on the Australian mainland and another on Lord Howe Island (Jacobs 1988), and their affinities to the rest of the genus have recently been analysed (Linder in prep.). However, there have been disputes about the correct names for the 'new' genera. Veldkamp (1980) proposed the conservation of Notodanthonia over Rytidosperma, and to change the typification of Plinthanthesis, replacing it with the new name Blakeochloa, but his arguments were opposed by Jacobs (1982), and the proposal was rejected. The delimitation of the new genera is still controversial, with Clayton and Renvoize (1986) proposing a wider concept of Rytidosperma, including Erythranthera, Karroochloa and Merxmuellera. Further, there are controversies about the recognition of some of the segregate genera, in particular Rytidosperma, in Australia (Conert 1975, 1987, Jacobs 1982). Despite the acceptance of Rytidosperma as a distinct genus in New Zealand and South America, it has not been generally accepted in Australia where Danthonia has been preferred (Jacobs 1982, 1994, Simon 1993, Beadle et al. 1982, Stanley \& Ross 1989, Walsh 1995, but see Blake 1972).

The danthonioid grasses are economically important in Australia as a high-quality native fodder (Whalley 1991, Mitchell 1991, Robards et al. 1967, Wilson \& Leigh 1970), particularly due to their drought resistance, their ever-green habit - they retain green, digestible leaves even in the dry seasons (Leigh 1991) - and their good response to grazing. In addition, danthonioids are common to dominant elements in the temperate grasslands of New South Wales, Victoria and Tasmania (Scott \& Whalley 1982, Lodge \& Whalley 1989). This has led to extensive ecological and biological research into the group, directed at understanding the dynamics of grasslands in paddocks (Scott \& Whalley 1984, Lodge \& Whalley 1989) and at the domestication of the more suitable species (Lodge \& Groves 1991). Consequently a stable taxonomy is of some importance. Generic delimitations in a widespread austral group like the danthonioid grasses cannot be done in continental isolation in Australia, and there have been two recent attempts at addressing the problem globally. Jacobs (1982) critically reviewed the evidence for segregating the genera, and Tomlinson (1985) surveyed the danthonioid grasses for anatomical and lodicule characters. However, neither of these two excellent studies presented comprehensive reviews of the available data, a task which would be necessary for the best evaluation of the evidence.

There is some doubt about the monophyly of the Arundinoideae. Phenetic morphological studies (Hilu \& Wright 1982) and an analysis of prolamin variation (Hilu \& Esen 1990) produced results consistent with a monophyletic Arundinoideae, although the sampling for the latter study was insufficient to test the hypothesis rigorously. Ellis (1987) failed to find leaf anatomical support for a monophyletic Arundinoideae, while the cladistic analyses of morphological data conducted by Kellogg and Campbell (1987) could not retrieve the Arundinoideae. A parsimony analysis of $r b c \mathrm{~L}$ sequence data demonstrated the polyphyly of the Arundinoideae (Barker et al. 1995). Until such time as a monophyletic subfamily classification is available, there appears to be little sense in using the subfamily classification, at least for the Arundinoideae. However, a large group of genera of the Arundinoideae are clearly related. Hilu and Esen (1990) showed that Danthonia s.l. and Cortaderia have very similar prolamins, and that these are rather different from the prolamins of the next most similar genus, Phragmites, as well as the rest of the grasses. This relationship was further demonstrated by both $r b c \mathrm{~L}$ (Barker et al. 1995) and $r p o C_{2}$ (Barker 1995) analyses, and in addition there are several morphological characters which define this clade: haustorial synergids (Philipson \& Connor 1984, Verboom et al. 1994), bilobed prophylls and ovaries with distant styles. There is as yet no formal taxonomy for this group, but as it is to some extent congruent with the tribe Danthonieae, as delimited by Watson and Dallwitz (1992), we refer to it in the rest of the paper as the 'danthonioid grasses'. 
Amphipogon and Diplopogon, which were included in the Danthonieae by Watson and Dallwitz (1992), are probably more distantly related, and may have closer relationships to other lineages. The exclusion of these taxa is based partially on the absence of the danthonioid synapomorphies, but in most cases the morphological evidence for the alternative placings has not yet been investigated, and current opinions on the affinities of these taxa are based on plastid genome sequences $\left(r b c \mathrm{~L}\right.$ and $\left.r p o \mathrm{C}_{2}\right)$.

Monachather Steudel was separated from Danthonia s.l. by Blake (1972) on the basis of the broadly turbinate, indurated lemma and the subquadrate caryopsis with the small elliptical hilum, as well as the woolly plant base. In addition, Watson and Dallwitz (1992) documented the presence of a lemma with a germination flap, and the structure of the lemma lobes is quite unlike any found in the danthonioids (pers. obs.). Morphologically the genus is quite distinct, and has been generally accepted (Jacobs 1994, Walsh 1995), but its relationships have remained obscure. Molecular data (Barker 1995) suggest a relationship to the Arundineae s.s. rather than to the Danthonieae, but its high ploidy level and bizarre morphology suggest that a more detailed analysis might be necessary to assess congruence of the plastid and nuclear genomes. As the molecular data (Barker et al. 1995) and morphological data (unpublished) indicate a rather distant relationship to the Danthonieae, the genus was not included in the present analysis.

It is clear that there is as yet no consensus as to what constitutes the best generic classification of the Australasian danthonioid grasses. This paper addresses the delimitation problems between Rytidosperma, Erythranthera, Pyrranthera, Monostachya and Danthonia, and constitutes an attempt to delimit monophyletic genera within this complex.

\section{Methodology}

Almost all species assigned to the danthonioid clade and related groups were studied morphologically and anatomically from herbarium material and, where available, from live plants. The descriptive data are being assembled in a DELTA data-base (Dallwitz 1980, Dallwitz \& Paine 1986). Selected species were studied embryologically (see Verboom et al. 1994). Further information, especially cytological information, was taken from the literature (for Australian material, Brock \& Brown 1961). The Australian species were studied from a large number of specimens, in preparation for the Flora of Australia account.

Spikelet, floret and caryopsis morphology were recorded both from whole-mounts of dissected spikelets in glycerine, and from dry dissections; measurements were taken with an eyepiece graticule precise to the nearest $0.1 \mathrm{~mm}$, and drawings were prepared by camera lucida. Continuous characters were used as ratios to prevent size variation having an unduly large effect. The ratios were divided into states at convenient intervals to reflect the range of the character variation: the character variation was not assessed for 'real' intervals in the variation range. However, as few taxa were polymorphic for the continuous characters, it is assumed that these intervals may be informative on relationships between taxa.

Leaf anatomical preparations were made from the midportions of the lower leaves fixed in FAA in the field, and stored in $70 \% \mathrm{EtOH}$. Where freshly fixed material was not available, herbarium material was rehydrated in boiling, soapy water. Transverse sections were hand-cut, while adaxial and abaxial epidermal scrapes were prepared by standard techniques. Preparations were stained in a combined Alcian Blue Safranin stain (Tolivia \& Tolivia 1987), dehydrated through an alcohol series, and mounted in Canada Balsam. 
The characters used are discussed in detail in the Appendix, and the distribution of the states given in Table 1.

Approximately 70 species are members of Rytidosperma sensu Zotov; of these, both morphological and anatomical data are available for 54 species, as well as for the species of Erythranthera and Pyrrhanthera. Closely related genera are represented by several species each (Karroochloa, two of four; Schismus, two of five; and Tribolium, three of ten) representing the variation within these genera. The 23 species of Danthonia are represented by six species. The tree was rooted to Pentaschistis curvifolia. Pentaschistis has haustorial synergids (Philipson \& Connor 1984, Verboom et al. 1994), which is a synapomorphy for the Danthonieae, but is not a member of the DanthoniaRytidosperma clade as it lacks the distinctive obovate caryopsis: it is thus a suitable outgroup taxon (Nixon \& Carpenter 1993).

Parsimony analysis was performed using Hennig86 (Farris 1988), run as a subroutine of DADA (Nixon 1993), and PAUP vs. 3.1 (Swofford 1993). Cladograms were prepared using CLADOS (Nixon. 1992). Several analyses were performed. An initial analysis included all 69 species, too large a set for detailed analysis. Initial trees for branch swapping were generated by multiple random input, using both PAUP and DADA. The set of shortest trees was then branch-swapped using TBR in PAUP and $b b^{*}$ in Hennig. However, in both searches the available memory was exhausted before completion of the search, so there might be shorter, as yet undiscovered, trees. The second analysis included a subset of 33 species selected to reflect variation within the group; these species were chosen to represent groups of similar species.

Successive weighting (Carpenter 1988) was used to choose among the set of most parsimonious trees. However, the results produced were generally at variance with the set of minimally parsimonious trees, and consequently these results were used to provide an assessment of the robustness of the various nodes. In addition, a bootstrap analysis with 100 replicates was conducted. Tree topologies and the costs of modifying tree topologies were explored using MacClade vs. 3 (Maddison \& Maddison 1992).

Characters were mapped on the strict consensus tree, using Accelerated Transformation (Swofford \& Maddison 1987), which prefers reversals to parallelisms when both optimisations are equally parsimonious. Anderberg and Tehler (1990) argued that it is illogical to plot characters on a consensus tree, as consensus trees are derived from the set of most parsimonious trees. However, this is not the issue: the characters are plotted on the the tree to illustrate which characters can be interpreted as synapomorphies for which clades.

\section{Results}

Analysis 1 could not be completed, due to lack of memory. Nine hundred and nine trees of length $=332$ steps, consistency index $=0.18$ and retention index $=0.62$ were found. The strict consensus tree is given in Fig. 1. Analyses with different starting trees, and with starting trees designed from the results of later analyses, produced essentially the same strict consensus tree, but with variation indicating that the set of trees located is somewhat different. The second analysis found four trees (length $=190$, consistency index $=0.295$ and retention index $=0.561$ ), with the only polychotomy being within Danthonia (Fig. 2).

Successive weighting did not lead to greater resolution, but provided some indication of the support for the various nodes (Fig. 3). The bootstrap results confirmed the low consistency index: very few nodes were retrieved in more than $50 \%$ of randomised data sets (Fig. 3). 


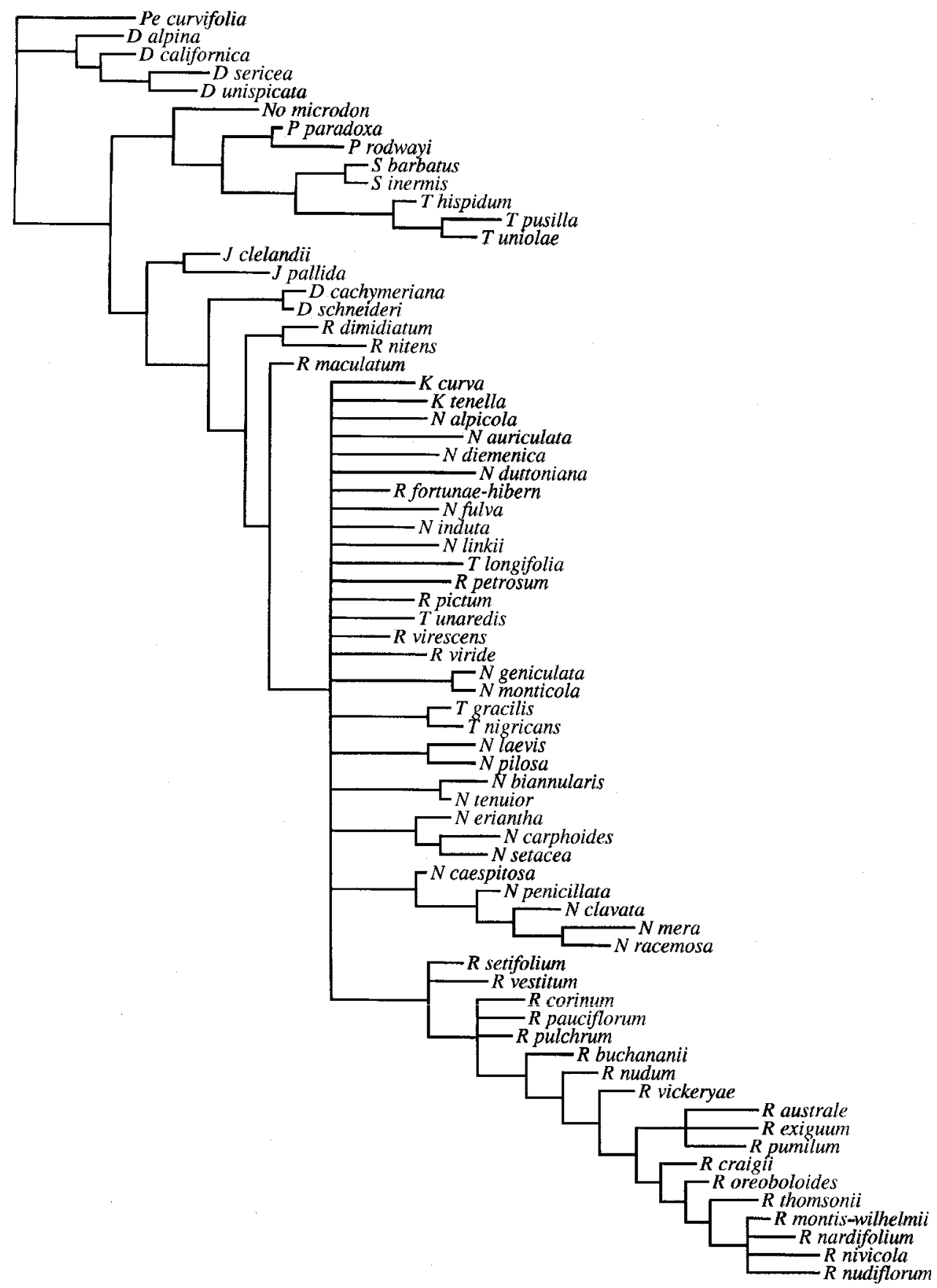

Fig. 1. Strict consensus tree from 909 equally parsimonious trees found for the complete set of species. Different starting trees generate somewhat different sets of trees. 


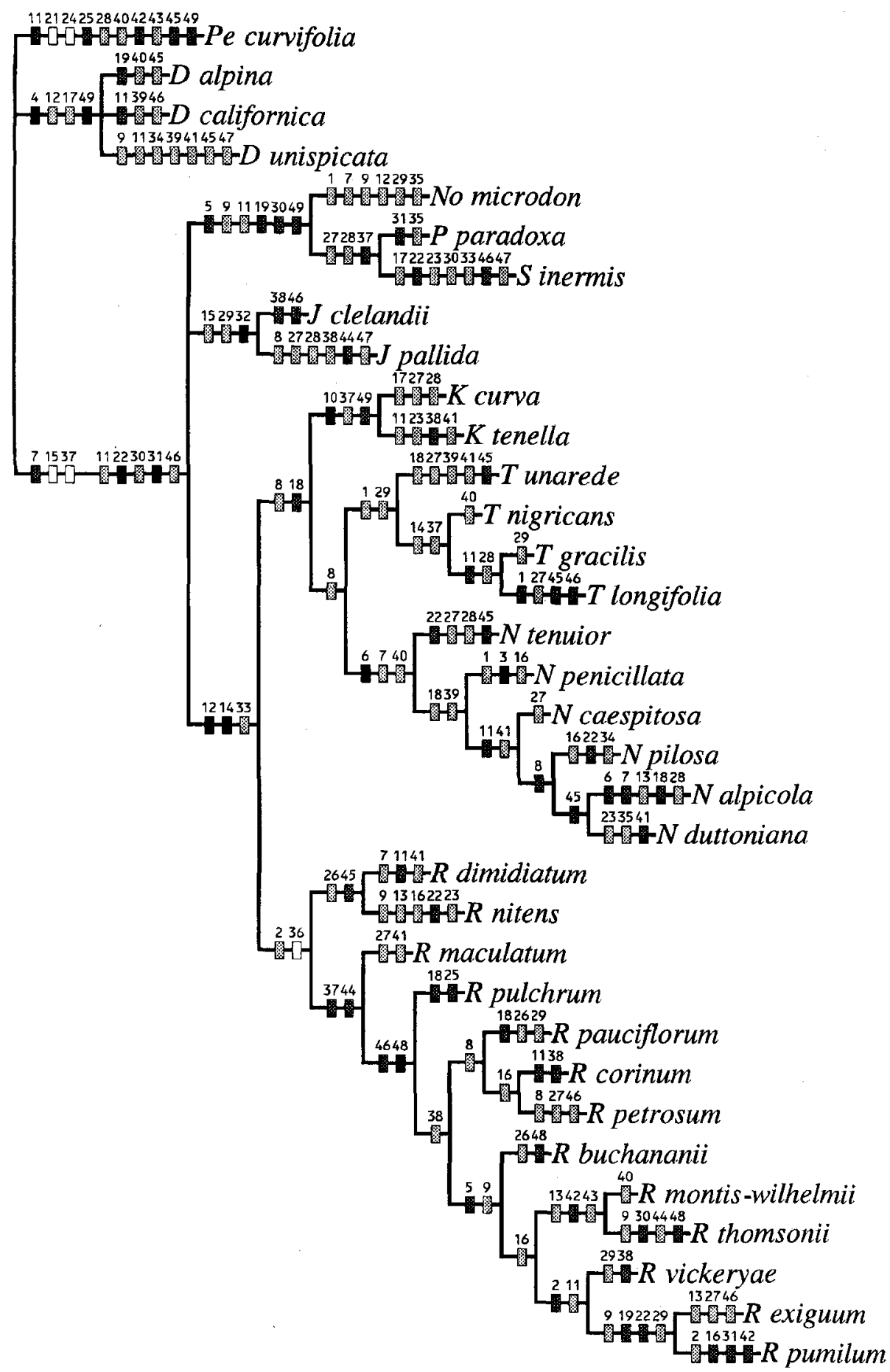

Fig. 2. Strict consensus tree from four equally parsimonious trees located for the subset of species. Characters have been optimised onto the topology to indicate support for the different clades. Filled bars indicate unique changes from 0 to 1 , or 1 to 2; hollow bars unique changes from 2 to 1 or 1 to 0 ; lightly shaded bars homoplasious changes from 2 to 1 or 1 to 0 ; darkly shaded bars homoplasious changes from 0 to 1 or 1 to 2 . 


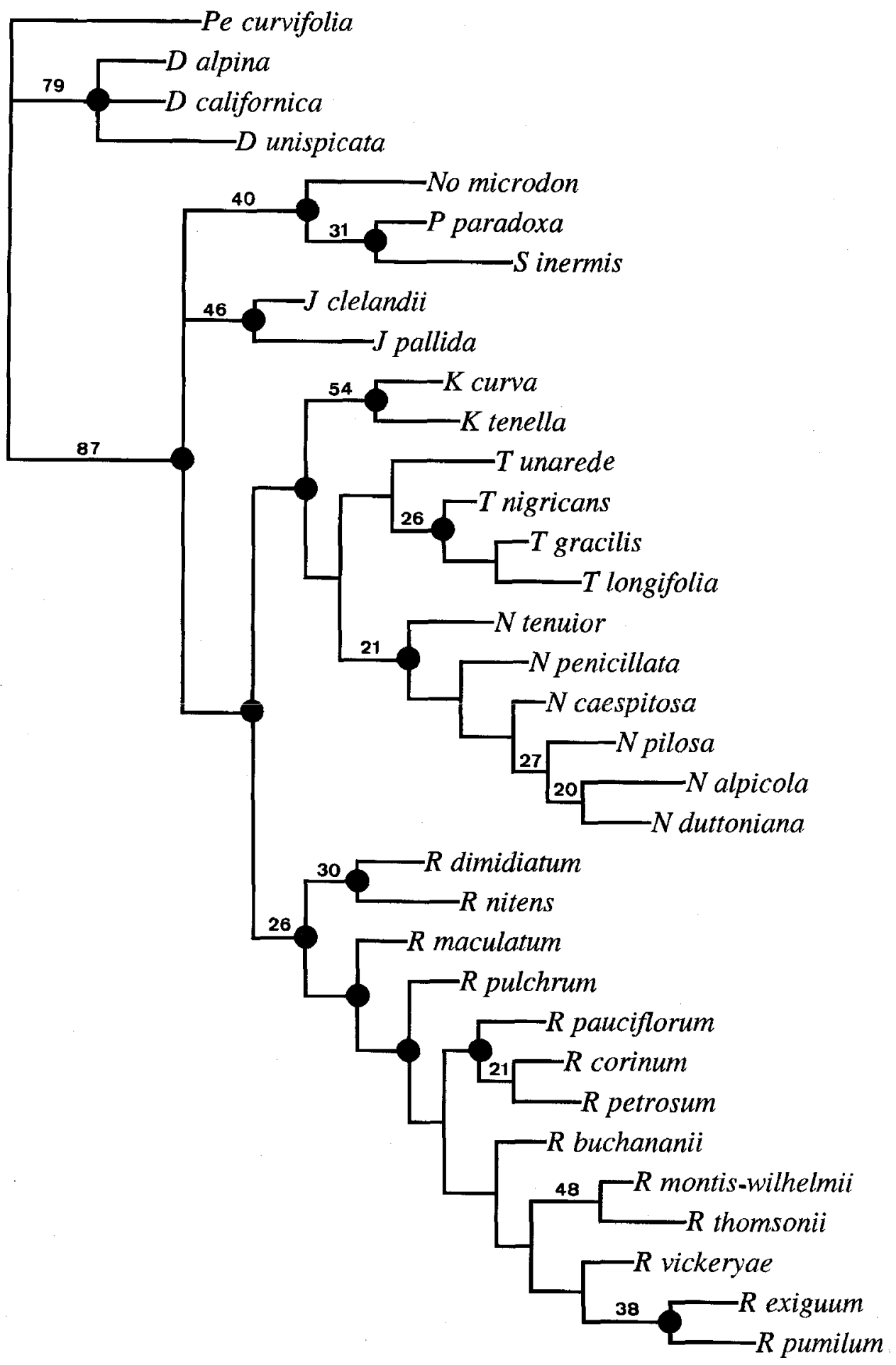

Fig. 3. Strict consensus tree from four equally parsimonious trees located from the subset of species. Nodes robust to successive weighting are indicated by dots; bootstrap percentiles are indicated by the numbers on the nodes. 


\section{Discussion}

The overall consistency indices and retention indices for the trees located are low. This is consistent with rampant convergence and parallelism, which is evident from the cladograms, showing the relatively low number of unique synapomorphies within this group. However, the basic pattern in the relationships was retrieved by all analyses, despite variations in the number of species included, variations in the characters used, etc., suggesting that the basic patterns located are robust.

A problem associated with the analysis of large data sets of often 'messy' data is that calculation times are slow, thus limiting the possibility of doing statistical tests based on character manipulations. In addition, such data sets often contain many possible arrangements of the taxa, which can limit the ability of the search algorithms to find the most parsimonious solutions. There are two sampling approaches to dealing with these problems: the first is to include as many species as possible, yet not be able to search the data set adequately; the other is to use a smaller set of representative species, but possibly miss important character combinations. The results of the first analysis almost certainly are not maximally parsimonious, while the results from the second analysis may represent an overly simplified picture.

Keeping these caveats in mind, the following interpretations can be made from these results.

\section{Danthonia}

The distinction between Danthonia and the Rytidosperma clade is strongly supported. This node was retrieved by all character and taxon manipulations, was unaltered by successive weighting, and obtained a bootstrap support value of $79 \%$.

Danthonia, as circumscribed here, is defined by the presence of cleistogenes among the culm sheaths and by a base chromosome number of 18 . With this definition, it includes 23 species, with nine in South America, eight in North America, and three from Europe to the Himalayas. Although none are native to Australia, Danthonia decumbens has been introduced in Tasmania and Victoria, where it is rather rare.

Zotov (1963) separated Rytidosperma from Danthonia by lemma indumentum and hilum shape. In Rytidosperma the lemma indumentum is tufted or patterned, while in Danthonia it is either evenly scattered on the back, or in marginal lines. The hilum in Rytidosperma is punctiform; in Danthonia it is linear. To these characters Veldkamp (1980) added ciliate lodicules and larger caryopses as typical of Rytidosperma. The two taxa also differ in basic chromosome number, with $2 n=24$ in Rytidosperma and 36 in Danthonia.

Jacobs (1982) critically analysed the characters used by Veldkamp (1980), and showed that there are exceptions to every character used by Veldkamp and Zotov. The lemma indumentum character is possibly the most difficult to quantify, as the distinction between the marginal strip of hair and the marginal tufts of a tufted indumentum is in many cases subjective. The hilum shape/length and lodicule indumentum characters have some striking exceptions in Danthonia, according to the data presented by Jacobs. However, from the data available, the exceptions are not correlated: species with bristly lodicules generally do not have short, punctate hila. Jacobs is particularly worried about the placement of $D$. cirrata, D. secundiflora and D. rhizomata. Yet in all three the lodicules are generally glabrous; and Tomlinson (1985) did not record bristles or microhairs for these species; only $D$. secundiflora has an oblong, short hilum; and D. cirrata has 72 chromosomes (either a tetraploid based on $2 n=36$, or a hexaploid based on $2 n=24$ ). D. unispicata has bristly lodicules, but the linear hilum 
is $75 \%$ of the length of the caryopsis. D. domingensis approaches Rytidosperma most closely by its bristly lodicules (Jacobs 1982), but Conert (1975) describes the lodicules as glabrous, raising the possibility that one of the authors was working with misidentified material. However, its chromosome number is 36 (Davidse \& Pohl 1972). It is necessary to decide whether these character distributions should be regarded as exceptions to the rule, or whether they should be interpreted as indicating a more complex pattern of relationships between Rytidosperma and Danthonia. If the exceptions were to some extent correlated, then they would probably indicate that Danthonia is nested within Rytidosperma. However, the exceptions occur singly, and Danthonia species with one Rytidosperma character do not have any others. We suggest that this indicates homoplasy, rather than a distinct pattern. We would therefore regard them as exceptions, rather than as intermediates between the two genera, and on a phylogenetic analysis they should appear as autapomorphies. Thus we interpret the data as indicating two distinct lineages: one for Rytidosperma and allied genera, and one for Danthonia.

The position of the Himalayan species Danthonia cachemyriana (including D. exilis and $D$. jaquemontii) and $D$. schneideri are not clear; Tomlinson (1985) suggested a relationship to Karroochloa, but there has never been a formal placement of these species outside Danthonia. The analysis of all species aligns them to the Rytidosperma s.l. clade rather than to Danthonia. In $D$. cachemyriana the lodicules have microhairs, the lemma indumentum is distinctly tufted, and the hilum $30 \%$ of the caryopsis length. D. schneideri also has lodicules with bristles and microhairs (Veldkamp, pers. com.), but the lemma indumentum is poorly tufted, with marginal strips of hair, and the hilum is $60 \%$ of the caryopsis length. However, despite these results we do not feel satisfied that we have seen enough good quality, convincing material to make the formal transfer of these species from Danthonia to Rytidosperma s.l.

All Danthonia species described from Malesia by Veldkamp $(1979,1993)$ should be included in the Rytidosperma s.l. clade: Veldkamp's descriptions and our own studies of some of the species indicate this clearly.

\section{Plinthanthesis, Schismus, Karroochloa and Notochloe}

This is a robust clade, which is retrieved by all analyses, and which is robust to bootstrapping. This clade is defined by a reduction in the degree of lobing of the lemmas, a reduction in the development of the lemma awns, the absence of a tufted indumentum on the abaxial surface of the lemma and the absence of bulliform cells. Our analyses indicate that Plinthanthesis is more closely related to Notochloe and Schismus than to either Danthonia or Rytidosperma. Although Plinthanthesis and Notochloe have very different spikelet morphologies, the spikelet morphology of Notochloe is unique, and so uninformative on its relationships. But the two genera share the presence of islands of clear cells between the vascular bundles. This is the only occurrence of this character in the danthonioid grasses (although it does occur in Phragmites, a member of the Arundineae s.s.), and so may be considered to be a good synapomorphy for them. In addition, this grouping is supported by the molecular analyses of Barker (1995). The two genera are associated with Danthonia by the mesic, moniliform leaf-blades and linear hila, but there is no direct morphological support for the molecular association between Danthonia and Plinthanthesis.

The association of Schismus and Tribolium with Plinthanthesis and Notochloe is interesting. Tribolium is endemic to southern Africa, while Schismus has most of its species there, with one species found around the Mediterranean. The group has no representatives in South America, unless the molecular data supporting the link to Danthonia are corroborated. 
Plinthanthesis has a complicated nomenclatural history. Bentham (1878) already separated it as Danthonia sect. Micranthera. Blake (1972) elevated this group to generic level, taking up Steudel's generic name Plinthanthesis, which he lectotypified by Plinthanthesis urvillei Steud., while transferring P. tenuius Steud. to Notodanthonia. Conert (1975) explicitly synonymised Plinthanthesis under Danthonia, by transferring the type species, P. urvillei Steud. to Danthonia, and Veldkamp (1980) challenged the typification of Plinthanthesis, an argument which was rejected by Jacobs (1982) and Connor and Edgar (1981). Our analysis supports the distinctness of Plinthanthesis, supported by four characters: villous palea margins, puberulous palea backs, and the absence of bulliform cells in the adaxial leaf epidermis. Blake used the characteristic brown colour of dried specimens, the remarkably long rhachilla internodes, the palea longer than the lemmas, and the glumes with prominent midnerves to separate Plinthanthesis from Danthonia s.s. and from Chionochloa, while Rytidosperma was separated from Plinthanthesis by a punctiform hilum.

\section{Joycea}

The two species of Joycea consistently form a distinct group, robust to successive weighting, often placed as sister-group to the rest of the Rytidosperma clade. These two represent a group of three species (of which two were used in the analysis): Joycea pallida, J. clelandii and the recently described J. lepidopoda. These three species lack the distinct tufting in the upper row of lemma hairs typical of Rytidosperma s.l., and also have more linear caryopsis hila, and the group is defined by its longer, deep red anthers.

Although this group has not been recognised before, J. pallida has always been considered to be taxonomically anomalous, and has consequently been placed in several genera: Veldkamp (1980) transferred the species to Notodanthonia, a position disputed by Connor and Edgar (1979), and Jacobs (1982) transferred the species to Chionochloa. Simon (1993), however, retained J. pallida in Danthonia. Vickery (1956) placed $J$. clelandii next to $D$. pallida, indicating the close relationship between them. Walsh (1991) also indicated the close relationship between his J. lepidopoda and J. pallida. Ecologically, the three species are quite distinct from the rest of the Rytidosperma clade, and especially J. pallida is not commonly regarded in Australia as a member of the genus Rytidosperma.

The morphological and ecological evidence indicates that this lineage may best be separated from typical Rytidosperma, so we separate the three species into a new genus, named Joycea after Joyce Vickery, who did such excellent work on the Australian grasses.

\section{Rytidosperma s.1.}

A clade including Rytidosperma sensu Zotov, Erythranthera, Pyrrhanthera, Monostachya and Karroochloa is retrieved by all analyses, and is robust to successive weighting. This clade is based largely on the lemma indumentum, which is more or less tufted, at least in the upper indumentum row. In addition, the hilum is more or less punctate. The hilum character is somewhat variable, as may be expected in such a large clade. Generally, the hilum is not truly punctate, but rather ovate to elliptical, and its size, relative to the caryopsis, is also variable. However, it is not linear, as is typical of so many other danthonioid genera. Consequently, simple measurements do not always capture the distinction between the different hilum types. It should be noted, though, that there are exceptions within both Rytidosperma s.l. and the rest of the tribe Danthonieae, so that this character is not absolute. 
Within this group four distinct lineages can be recognised. These lineages are retrieved by the smaller analysis: only one is distinct in the larger analysis, in which substantial resolution is lost. This loss of resolution could be due to the inclusion of taxa with different character combinations, thereby breaking up the characters that define the subclades. It is striking, though, that the obvious characters which define the clades do not have exceptions. This indicates that convergences in other characters break up these clades.

The taxonomic rank of the four clades, relative to the broader Rytidosperma, is problematic, and they either be recognised as subgenera of a broad Rytidosperma s.l., or as distinct genera. The arguments for recognising a broad Rytidosperma s.l. are as follows:

a) This is taxonomically conservative, as this is the sense in which Zotov and Connor and Edgar used the genus, and the grasses in Australasia that were previously referred to as Danthonia will now be called Rytidosperma.

b) This usage is consistent. with common-name usage, where all Australian species of Rytidosperma s.l. are referred to as 'Wallaby grasses'. The most common Australian Rytidosperma s.l. species belong to one clade, so that even with a fragmented classification, 'Wallaby grasses' would still largely refer to Notodanthonia s.s.

c) It may result in fewer name changes than a finer subdivision of the genus. However, due to the name changes proposed by Veldkamp (1980) not many new combinations would result from the fragmentation of Rytidosperma.

d) The node on which the genus will be based was retrieved by all the analyses with different combinations of taxa, thus there is a good likelihood that this node is phylogenetically robust.

Arguments that can be mustered for recognising the four clades as genera are as follows:

a) Rytidosperma s.l. is a large genus, including 72 species. This is unwieldy; smaller genera are easier to understand and to work on. Subdivision would establish genera of $28,35,4$ and 5 species.

b) The inclusion of Karroochloa under Rytidosperma appears unlikely from cytogenetic grounds. We suspect that its inclusion within the Rytidosperma complex may be due to convergence. Recognising the narrower genera avoids implicating taxonomic changes in phylogenetic changes.

c) The four clades are eco-geographically quite distinct. If taxonomic ranks should be established at nodes at which they are maximally predictive, then the recognition of the four as genera, rather than one variable genus, might be more informative. This would be consistent with the ecogeographical differences between Joycea, Plinthanthesis, and Notochloe.

Morphological support is rather equivocal. Rytidosperma s.l. can be diagnosed by the usually tufted lemma indumentum: but there are exceptions, and the definition of tuftedness would have to be precise to avoid confusion with the African Merxmuellera. Two of the smaller clades can be diagnosed by a single, unambiguous character, the remaining two by character combinations. Thus for both rankings, most species can be keyed to the genus without difficulty, but there are some species which are difficult to place.

On the balance of the evidence, we recognise four segregate genera, but are aware that there is an almost equally strong case for recognising a single, large genus Rytidosperma. 


\section{Karroochloa}

Karroochloa includes four species, in two very distinctive groups. Within an African context there is no possibility of confusing these two species groups with any other grasses, as they are the only members of Rytidosperma s.l. in Africa, but it is more difficult finding a synapomorphy combining them in a global context, and the only morphological synapomorphy found is a rounded sinus base. In addition, Karroochloa is the only diploid group in Rytidosperma s.l., the rest of the group being tetraploid or with higher ploidy levels. The four species are very variable in terms of lemma indumentum.

Clayton and Renvoize (1986) suggested inclusion of Karroochloa, as well as Merxmuellera, in Rytidosperma s.l. Merxmuellera is very variable, and most likely contains several disparate elements which are not closely related (see also comments in Tomlinson 1985, Ellis 1982, Barker \& Ellis 1991). There is no indication from the leaf anatomy for a relationship with Rytidosperma, and the caryopsis shape is quite different (Barker 1994). Although the lemma indumentum of several species of Merxmuellera is tufted, these tufts do not form regular transverse rows as is typical of most species of Rytidosperma. Karroochloa is indeed very close to Rytidosperma s.l., and the only character by which it can be separated is the chromosome number of $2 n=12$. However, its inclusion in the Rytidosperma s.l. clade would appear to be unlikely, and would need to be investigated further. We suggest that placing the two Karroochloa species within Rytidosperma may be erroneous, and the result of convergence between the two genera. The chromosome numbers indicate that Karroochloa should occupy a basal position relative to the rest of the clade, as it is highly unlikely that there could be a reversal of a diploid number of 24 to 12 . We would like to see Karroochloa to be the sister group to the $2 n=24$ Rytidosperma clade. Nonetheless, the most parsimonious solution suggests that the diploid doubling either occurred three times, or that the reversal did in fact occur. Forcing Karroochloa to a basal position, followed by a single doubling in the chromosome number, results in an increase in tree length from 193 to 196 steps.

\section{Rytidosperma s.s.}

The most distinctive subclade, containing Monostachya, Erythranthera and Pyrrhanthera, as well as about half of Rytidosperma sensu Zotov, is defined by the presence of disarticulating leaf blades and narrow metaxylem vessels. Zotov (1963) recognised part of the group as Notodanthonia sect. Buchanania Zotov, defined by the folded, glabrous leaves, red anthers, narrow paleas and short lemma lobes, and separated other parts of the clade as the segregate genera Erythranthera and Pyrrhanthera. Although the leaf indumentum, palea shape and anther colour characters have exceptions among the Australian and New Guinean taxa, this remains a rather distinct group of small plants with tough, folded, usually deciduous leaves, and with the upper row of lemma hair tufts weakly defined, often more or less reduced. The species are numerous and common in New Zealand; in Australia and New Guinea the plants are found in montane or alpine habitats. Zotov, and Connor and Edgar (1979), who largely agreed with Zotov's infrageneric classification of Rytidosperma, did not consider Monostachya, Erythranthera and Pyrrhanthera to be part of this clade. The South American species of Rytidosperma all belong to this clade, too.

Monostachya was originally described for $R$. oreoboloides; Jacobs (1982) also included $R$. craigii, $R$. montis-wilhelmii and $R$. nardifolia, and argued for the separation of Monostachya from Rytidosperma. Veldkamp (1980), while arguing for the inclusion of Monostachya in Rytidosperma, listed (a) the cushion growth-form, (b) inflorescence reduced to one spikelet, (c) the shortly bidentate and aristate inflorescences and 
(d) a base chromosome number of $n=5$ (if correct) as insufficiently differentiating characters. Jacobs (1982) added (e) the absence of abaxial microhairs and (f) circular silica bodies, and argued for the retention of the genus.

Several of the characters suggested by Veldkamp and Jacobs are more widespread in Rytidosperma, even if in less developed form. Reduction in the inflorescence forms a continuum, and the development of spike-like inflorescences has also occurred several times. The development of a bidentate and aristate, or even an acute lemma apex, appears to be the consequence of the fusion of the lemma lobes to the awn column. Intermediate forms of fusion are common in this clade, and similar fusion patterns have been observed in the African genera Tribolium and Prionanthium. Detailed observations of the lemma vasculature further corroborate the derivation of bidentate lemmas in this group from a bilobed lemma. Awn reduction is more complex, in some groups the column is lost, leaving only the apical setum (e.g. in Tribolium and Monostachya), in others the strap-like column is retained, which may show some twisting (e.g. Plinthanthesis). Cushion-like growth-forms also appear to occur in some New Zealand species of sect. Buchanania. The reported base chromosome number $(2 n=10)$ of $R$. oreoboloides is unusual for the clade, and requires corroboration. The anatomical peculiarities (absence of abaxial microhairs and shape of the silica bodies) are also more widespread in Rytidosperma s.s. (see Table 1), and may even be found in some South American species (Tomlinson 1985). These character distribution patterns are matched by the gradual reduction in the lemma indumentum, culminating in several species with glabrous abaxial lemma surfaces. As noted by Jacobs (1982), Monostachya is indeed a distinct group; however, it is embedded in the Rytidosperma s.s. clade, and many of the peculiarities of the high altitude New Guinean species may be regarded as specialisations to the anomalous tropic alpine environment. Recognition of Monostachya would firstly require some indication of the degree of inclusiveness of the group, but essentially the whole of the Rytidosperma s.s. clade would have to be included in order to delimit monophyletic taxa. Monostachya, as delimited by Jacobs (1982), renders Rytidosperma paraphyletic.

Erythranthera was described by Zotov (1963), distinguished by the minutely threetoothed, awnless lemma, and a long bare rachilla internode associated with a short callus borne at right angles to the internode. This genus includes two rare species, which are found in long-lying snow-drifts.

Pyrrhanthera is a monotypic genus from New Zealand, separated by Zotov (1963). It has a unique growth-form in the Rytidosperma group, with long, spreading rhizomes, and very sparsely flowering aerial shoots. In addition, the fruit is a nutlet, with a separable wall.

Blake (1972) accepted Erythranthera without any critical discussion; Tomlinson (1985) does not pronounce on the desirability or otherwise of recognising these genera, commenting merely that the leaf anatomy does not support them, but that glabrous lodicules are indeed rare in Rytidosperma. Clayton and Renvoize (1986) recognise only Pyrrhanthera, presumably due to the fruit. Both genera have unique characters, which constitute the basis on which they were recognised. The three species in these two genera, like those included by Jacobs in Monostachya, are indeed peculiar. However, they share the leaf anatomy and basic spikelet morphology of the Rytidosperma s.s. clade, and may represent specialisations from this basic condition. As with Monostachya, recognising them would result in a paraphyletic Rytidosperma, consequently we suggest including them in Rytidosperma. They appear to represent specialisation to peculiar habitats. Erythranthera is usually found in snow-hollows, both in Australia and in New Zealand. Pyrrhanthera is found in arid plains on the lee of the New Zealand alps. 


\section{Thonandia}

The T. longifolia clade is defined primarily by the abaxial lemma surface indumentum, which consists of a short, even indumentum, terminating abruptly in the long tufted hairs of the upper indumentum row. In addition, the lemma lobes are very long with short setae, and the inflorescences are lax, often linear, with pale-green spikelets. Three of the five species have extravaginal innovations. These grasses are generally found in semi-shaded habitats in open woodland, and along rain-forest margins. They appear to avoid open grasslands and full-sun habitats where they would get heavily frosted, being found along the slopes of the escarpment, but never on the Tablelands: in the A.C.T. they are found only on the steep slopes of the gorges, growing in light shade. This clade includes T. semiannularis, T. longifolia, T. gracilis, T. nigricans and T. unarede. A similar indumentum is also found in the West Australian $N$. occidentalis, but this peculiar species also shows some characters of the $N$. caespitosa clade, and will be discussed in more detail under Notodanthonia.

This segregate has not been recognised before. Zotov (1963) established a subsection Semiannularia, which included $N$. tenuior, N. biannularis and T. semiannularis. He defined the group by its scattered lemma-back hairs, and the relatively short setae on the lemma lobes. Vickery (1956) also placed the species of this group together. There is therefore no formal name available for this genus, and we name it Thonandia, which is an anagram for Danthonia.

\section{Notodanthonia}

The Notodanthonia clade is defined primarily by the massively enlarged callus, and the correspondingly minute rachilla internode. In addition, the leaf blades are generally softly hairy. The abaxial lemma surfaces generally have two neat rows of tufted indumentum, but in several species there are scattered hairs between the rows, while in some other species the lower row is diffuse. However, the indumentum below the upper row never forms a short, even indumentum as in Thonandia. This is a large clade, that has diversified on the Australian tablelands: it includes 28 species. The species are virtually restricted to sunny grasslands, although some species may also be found in light shade in open woodland (e.g. N. penicillata, N. carphoides). This is the group that has become economically important as pasture grasses, and for this reason several species have been introduced into New Zealand. The species are mostly closely related to each other, and difficult to distinguish, with many intermediate forms. The group contains substantial variation in the lemma indumentum, as well as the shape of the palea, and subgroups within it may be recognised on this basis.

Two species are somewhat problematic. $N$. occidentalis has the massive callus typical of this group, but the lemma indumentum is like that of Thonandia. However, in all other respects the species is rather like $N$. acerosa, and the most likely interpretation of the indumentum character would be a convergence to Thonandia. N. alpicola is somewhat more difficult. It lacks the typically massive callus of the genus, but is also peculiar in several other characteristics like the thickened leaves. Its closest relative is probably $N$. caespitosa, and Vickery regarded it as an alpine variant of that species. The smaller callus is consequently regarded as a reversal.

Zotov (1963) included the New Zealand species of this group in his section Semiannularia, together with the species of Thonandia mentioned above: however, no further attempt had been made to recognise this group of species. 


\section{Formal taxonomy}

This is a key to the genera in the Rytidosperma complex and Notochloe, Schismus and Plinthanthesis, which have been adequately diagnosed in the literature, are not included in this key.

1 Lemma sinus rounded; plants African

Karroochloa

$1^{*}$ Lemma sinus acute, plants circum-Pacific

2 Callus $0.7-0.95$ times the combined length of callus and rhachilla internode

Notodanthonia

$2^{*}$ Callus less than 0.7 times the combined length of callus and rhachilla internode

3 Abaxial lemma surface indumentum in two untidy rows, or largely with a glabrous, shiny back; leaves often disarticulating from the sheath

Rytidosperma

$3^{*}$ Abaxial lemma surface with a more or less continuous felt-like indumentum, with at most the upper margin of this tufted; leaves not disarticulating from the sheath

4 Upper row of tufts absent; anthers 1.2-5.2 $\mathrm{mm}$ long, red Joycea

$4^{*}$ Upper row of hair tufts present; anthers $0.7-1.7 \mathrm{~mm}$ long, yellow to orange ......

Thonandia

Joycea Linder, gen. nov., Rytidospermati similis, sed lemmatis indumento disperso et caryopsidis hilo longiore magis lineareque et antheris longis rubrisque differt. Type: Joycea pallida (R. Br.) Linder

Caespitose or rhizomatous grasses with intravaginal innovations and truncate, twoawned prophylls, plants more or less glabrous. Inflorescence an open panicle. Spikelets with 3-6 florets; disarticulating between the florets, callus blunt, villous, as long as rhachilla internode. Glumes equal, 1-7-nerved, glabrous to scaberulous along the veins, taller than the floret packet, acute. Lemmas 9-veined, bilobed, with the 3 central veins fusing at the base of the geniculate awn, and the 3 lateral veins entering the acuminate lemma lobes; lemma indumentum of scattered long hairs covering the abaxial lemma surface. Awn column flat, cork-screwed, limb long and acute. Paleas longer than the lemma sinus, linear, truncate to bilobed, keeled, glabrous or villous between the keels and usually with hair-tufts on the palea margins. Lodicules 2, rhomboid, bristly and with microhairs. Anthers 3, large, red to purple. Ovary stalked, glabrous; stigmas distant and separated by a small double ridge. Caryopsis obovate, embryo half the length of the caryopsis, hilum $20-30 \%$ of caryopsis length, linear to ovate. Chromosome numbers $48,72,96$.

This new genus is similar to Rytidosperma, but differs by the scattered lemma indumentum, the longer and more linear caryopsis hilum, and the long, red anthers. It contains three species, from South Australia, Victoria, New South Wales, Australian Capital Territory and Queensland.

Joycea pallida ( $R$. Br.) Linder, comb. nov.

Basionym: Danthonia pallida R. Br., Prod.: 177 (1810). Avena brownii Spreng., Syst. Veg. 1: 336 (1825), non A. pallida Thunb. Notodanthonia pallida (R. Br.) Veldk., Taxon 29: 297 (1980). Chionochloa pallida (R. Br.) Jacobs, Taxon 31: 742 (1982). 
Danthonia penicillata (Labill.) Beauv. var. pallida (R. Br.) F. Muell. ex Maiden and Betche, Census New South Wales Plants: 29 (1922).

Type: $R$. Brown '6232' (BM, holo, K!).

Joycea clelandii (Vickery) Linder, comb. nov.

Basionym: Danthonia clelandii Vickery, Contrib. New South Wales Nat. Herb. 1: 297 (1950). Rytidosperma clelandii (Vickery) Connor and Edgar, New Zealand J. Bot. 17: 332 (1979).

Type: South Australia: Upper Waterfall Gully, Cleland H. 262, 30 Oct 1926 (NSW 1126, holo!; JBC iso).

Joycea lepidopoda (Walsh) Linder, comb. nov.

Basionym: Danthonia lepidopoda Walsh, Muelleria 7: 384 (1991).

Type: Victoria: 'Bullens Land' Courtneys Road, north of Ash Reserve, Walsh 1709 (MEL holo!; NSW, BRI iso).

Thonandia Linder, gen. nov., a Rytidospermate Steud. lemmatis indumento disperso breveque quit distincto a pilis superis longisque; et a Notodanthonia Zotov callo parva recedit.

Type: Thonandia longifolium (R. Br.) Linder

Caespitose or rhizomatous grasses with intra- or extravaginal innovations and truncate, two-awned prophylls, plants villous or glabrous. Inflorescence an open panicle. Spikelets $6-16 \mathrm{~mm}$ long and with 2-7 bisexual florets; disarticulating between the florets, callus blunt, villous, approximately as long as rhachilla internode. Glumes equal, 3-7-nerved, glabrous to scaberulous along the veins, taller than the floret packet, acute. Lemmas 9-veined, bilobed, with the 3 central veins fusing at the base of the geniculate awn, and the 3 lateral veins entering the acuminate lemma lobes; lemma indumentum of short hairs covering the abaxial lemma surface, with an abrupt transition to a row of long, tufted hairs shorter to longer than the lemma lobes; lemma lobes at least as long as lemma body; lemma lobe setae shorter than the lemma lobes. Awn column flat, cork-screwed, shorter than the lemma lobes; limb long and acute. Paleas longer than the lemma sinus, linear, truncate to bilobed, keeled, glabrous or villous between the keels and usually with hair-tufts on the palea margins. Lodicules 2, cuneate to rhomboid, bristly and with microhairs. Anthers 3 , yellow to orange. Ovary stalked, glabrous; stigmas distant and separated by a small double ridge. Caryopsis obovate, embryo half the length of the caryopsis, hilum $20-30 \%$ of caryopsis length, elliptical to oblong. Chromosome numbers $24,48$.

This new genus differs from Rytidosperma by the short, felt-like indumentum on the lemma sharply distinct from the upper row of hairs, and from Notodanthonia by the relatively short callus. It contains five species, from Australia and New Zealand.

Thonandia gracilis (Hook. f.) Linder, comb. nov.

Basionym: Danthonia gracilis Hook. f., Fl. New Zealand 1: 303 t.69B (1853). D. semiannularis (Labill.) R. Br. var. gracilis (Hook. f.) Hook. f., Handb. New Zealand Fl. 333 (1864). Notodanthonia gracilis (Hook. f.) Zotov, New Zealand J. Bot. 1: 123 (1963). Rytidosperma gracile (Hook. f.) Connor \& Edgar, New Zealand J. Bot. 17: 330. Type: New Zealand: Rotoiti Lake, Aglionby Plains, Munro 120/2 (holo, K).

Thonandia nigricans (Petrie) Linder, comb.nov.

Basionym: Danthonia semiannularis (Labill.) R. Br. var. nigricans Petrie, Trans. New Zealand Inst. 46: 37 (1914). Danthonia nigricans (Petrie) Calder, J. Linn. Soc. Lond. Bot. 51: 8 (1937). Danthonia gracilis Hook. f. var. nigricans (Petrie) Zotov, Trans. Royal 
Soc. New Zealand 73: 234 (1943). Notodanthonia nigricans (Petrie) Zotov, New Zealand J. Bot. 1: 123 (1963). Rytidosperma nigricans (Petrie) Connor \& Edgar, New Zealand J. Bot. 17: 331 (1979).

Type: New Zealand: Mt Hector, Petrie s.n. (WELT 40273A, holo).

Thonandia longifolia (R. Br.) Linder, comb. nov.

Basionym: Danthonia longifolia R. Br., Prod. 176 (1810); Avena longifolia (R. Br.) Spreng., Syst. 1: 336 (1825); Rytidosperma longifolium (R. Br.) Connor \& Edgar, New Zealand J. Bot. 17: 332 (1979); Notodanthonia longifolia (R. Br.) Veldk., Taxon 29: 296 (1980).

Type: New South Wales: Port Jackson, Brown 6231 (BM, holo, K!; fragm. PERTH!)

Thonandia semiannularis (Labill.) Linder, comb. nov.

Arundo semiannularis Labill., Pl. Nov. Holl. 1: 26 t.33 (1804); Danthonia semiannularis (Labill.) R. Br., Prod. 177 (1810); Rytidosperma semiannulare (Labill.) Connor \& Edgar, New Zealand J. Bot. 17: 332 (1979); Notodanthonia semiannularis (Labill.) Zotov, New Zealand J. Bot. 1: 116 (1963).

Type: see notes in Vickery: photos at K of spec. no. 114 from Herb. Webb, but these cannot really be identified with confidence.

Thonandia unarede (Raoul) Linder, comb. nov.

Danthonia unarede Raoul, Ann. Sci. Nat. Ser. 3,2: 116 (1844); Danthonia semiannularis (Labill.) R. Br. var. unarede (Raoul) Hook. f., Fl. New Zealand 1: 304 (1853); Notodanthonia unarede (Raoul) Zotov, New Zealand J. Bot. 1: 122 (1963). Type: New Zealand: Banks Peninsula, Raoul 1843 (P, holo, K).

Danthonia cingula Steud., Syn. Pl. Glum. 1: 246 (1854).

Type: New Zealand: Kampmann 99 (P, holo)

Rytidosperma Steud., Syn. 1: 425 (1854). Type species: R. lechleri Steud. Monostachya Merr. in Merrill \& Merritt, Phil. J. Sci., Bot. 5: 330

Type species: $M$. centrolepidoides Merr. (= M. oreoboloides (F. Muell.) Hitchc.).

Includes 35 species and several subspecies, ranging from South America through Australasia to Malesia.

Rytidosperma australe (Petrie) Linder, comb. nov.

Basionym: Triodia australis Petrie, Trans. Proc. New Zealand Inst. 22: 442 (1890). Danthonia australis (Petrie) Zotov, Trans. Proc. Royal Soc. New Zealand 73: 234 (1943) non Danthonia australis Buchan. Erythranthera australis (Petrie) Zotov, New Zealand J. Bot. 1: 125 (1963). Type: New Zealand: Mt Ida Range, Petrie s.n. (WELT holo).

Rytidosperma buchananii (Hook. f.) Connor \& Edgar

Rytidosperma corinum Connor \& Edgar

Rytidosperma craigii (Veldk.) Linder, comb. nov.

Basionym: Danthonia craigii Veldk. in Van Royen, The Alpine Flora of New Guinea 2: 1172 (1979). Notodanthonia craigii (Veldk.) Veldk., Taxon 29: 298 (1980). Monostachya craigii (Veldk.) Jacobs, Taxon 31: 739 (1982).

Type: Veldkamp 6472 (L, holo; A, K, LAE, NSW! iso).

Rytidosperma dendeniwae (Veldk.) Linder, comb. nov.

Basionym: Danthonia dendeniwae Veldk., Blumea 38: 218 (1993).

Type: Papua New Guinea: Northern Province: Mt Suckling, Veldkamp \& Stevens 5768 (L, holo). 
Rytidosperma dimidiatum (Vickery) Connor \& Edgar

Rytidosperma exiguum (Kirk) Linder, comb. nov.

Basionym: Triodia exigua Kirk, Trans. Proc. N.Z.I. 14: 378 (1882); Danthonia exigua (Kirk) Zotov, Trans. Proc. Roy. Soc. New Zealand 73: 234 (1943); Pyrranthera exigua (Kirk) Zotov, New Zealand J. Bot. 1: 126 (1963).

Type: New Zealand: Thomas River, Waimakariri, Kirk s.n. (WELT, holo).

Rytidosperma fortunae-hibernae (Renvoize) Connor \& Edgar

Rytidosperma irianense (Veldk.) Linder, comb. nov.

Basionym: Danthonia irianensis Veldk., Blumea 38: 218 (1993).

Type: Irian Jaya: Carstensz, Carstensz Meadow, Hope ANU 10952 (L, holo; BO, CANB iso).

Rytidosperma javanicum (Ohwi ex Veldk.) Linder, comb. nov.

Basionym: Danthonia javanica Ohwi ex Veldk., Blumea 38: 219 (1993).

Type: Java: Mt. Lawu, Afriastini 264 (L, holo; BO, K, P iso).

Rytidosperma lechleri Steud.

Rytidosperma maculatum (Zotov) Connor \& Edgar

Rytidosperma mamberamense (Jansen) Connor \& Edgar

Rytidosperma montis-wilhelmii (Veldk. \& Fortuin) Linder, comb. nov.

Basionym: Danthonia montis-wilhelmii Veldk. \& Fortuin in Van Royen, The Alpine Flora of New Guinea 2: 1172 (1979). Notodanthonia montis-wilhelmii (Veldk. \& Fortuin) Veldk., Taxon 29: 298 (1980). Monostachya montis-wilhelmii (Veldk. \& Fortuin) Jacobs, Taxon 31: 739 (1982).

Type: van Balgooy 559 (L, holo; A, CANB!, LAE iso).

Rytidosperma nardifolium (Veldk.) Linder, comb. nov.

Basionym: Danthonia nardifolia Veldk. in Van Royen, The Alpine Flora of New Guinea 2: 1174 (1979). Notodanthonia nardifolia (Veldk.) Veldk., Taxon 29: 298 (1980). Monostachya nardifolia (Veldk.) Jacobs, Taxon 31: 739 (1982).

Type: New Guinea: Craven 3023 (L, holo; A, CANB!, LAE iso)

Rytidosperma nitens (D. Morris) Linder, comb. nov.

Basionym: Danthonia nitens D. Morris, Muelleria 7: 155 (1990).

Type: Fletcher s.n. (HO 30982, holo!)

Rytidosperma nivicolum (Vickery) Connor \& Edgar

Rytidosperma nudiflorum (P. Morris) Connor \& Edgar

Rytidosperma nudum (Hook. f.) Connor \& Edgar

Rytidosperma oreoboloides (F. Muell.) Linder, comb. nov.

Basionym: Festuca oreoboloides F. Muell., Trans. Roy. Soc. Vict. 1: 39 (1889). Danthonia oreoboloides (F. Muell.) Stapf in Hooker, Ic. Pl. t. 2606 (1899). Monostachya oreoboloides (F. Muell.) Hitchcock, Brittonia 2: 107 (1936). Notodanthonia oreoboloides (F. Muell.) Veldk., Taxon 29: 298 (1980).

Types: Papua New Guinea: Mt. Knutsford, MacGregor s.n. (K!, BM!); Mt Scratchley, $12200 \mathrm{ft}, 1896$, Giulianetti s.n. (K, lecto!, MEL). 
Rytidosperma paschalis (Pilger) Baeza

Rytidosperma pauciflorum (R. Br.) Connor \& Edgar

Rytidosperma petrosum Connor \& Edgar

Rytidosperma pictum (Nees \& Meyen) Nicora

Rytidosperma pictum (Nees \& Meyen) Nicora var. bimucronatum Nicora

Rytidosperma pulchrum (Zotov) Connor \& Edgar

Rytidosperma pumilum (Kirk) Linder, comb. nov.

Basionym: Atropis pumila Kirk, Trans. Proc. New Zealand Inst. 14: 379 (1882). Triodia pumila (Kirk) Hack. ex Cheeseman, Manual New Zealand Fl.: 896 (1906). Danthonia kirkii Zotov, Trans. Proc. Roy. Soc. New Zealand 73: 234 (1943), non Danthonia pumila Nees. Erythranthera pumila (Kirk) Zotov, New Zealand J. Bot. 1: 124 (1963).

Type: New Zealand: Macraes, Otago, Petrie s.n. (WELT holo).

Rytidosperma setifolium (Hook. f.) Connor \& Edgar

Rytidosperma sorianoi Nicora

Rytidosperma tenue (Petrie) Connor \& Edgar

Rytidosperma thomsonii (Buchanan) Connor \& Edgar

Rytidosperma vestitum (Pilg.) Connor \& Edgar

Rytidosperma violaceum (Desv.) Nicora

Rytidosperma virescens (Desv.) Nicora

Rytidosperma virescens (Desv.) Nicora var. parvispiculum Nicora

Rytidosperma virescens (Desv.) Nicora var. patagonicum (Spegazzini) Nicora

Rytidosperma viride (Zotov) Connor \& Edgar

Notodanthonia Zotov, New Zealand J. Bot. 1: 104 (1963).

Type species: Notodanthonia unarede (Raoul) Zotov.

Includes 28 species from New Zealand, Australia and Papua New Guinea.

Notodanthonia acerosa (Vickery) Veldk.

Notodanthonia alpicola (Vickery) Veldk.

Notodanthonia auriculata (J.M. Black) Zotov

Notodanthonia biannularis Zotov

Notodanthonia bonthainica (Jansen) Linder, comb. nov.

Basionym: Danthonia pilosa R. Br. var. bonthainica Jansen, Reinwardtia 2: 258 (1953).

Notodanthonia penicillatua (R. Br) Zotov ssp. bonthainica (Jansen) Veldk., Taxon 29: 298 (1980). Danthonia bonthainica (Jansen) Veldk., Blumea 38: 217 (1983).

Type: Celebes: Peak on Bonthaim, Buennemeijer 11971 (BO, holo; L iso).

Notodanthonia caespitosa (Gaud.) Zotov

Notodanthonia carphoides (Benth.) Zotov

Notodanthonia clavata Zotov 
Notodanthonia diemenica (D.F. Morris) Linder, comb. nov.

Basionym: Danthonia diemenica D. Morris, Muellera 7: 153 (1990).

Type:Tasmania: Ouse River, Wild Dog Plains, Moscal 1292 (HO 65782, holo!).

Notodanthonia duttoniana (Cashmore) Veldk.

Notodanthonia eriantha (Lindl.) Veldk.

Notodanthonia fulva (Vickery) Linder, comb. nov. et stat. nov.

Basionym: Danthonia linkii Kunth var. fulva Vickery, Contrib. New South Wales Nat. Herb. 1: 299 (1950); Rytidosperma linkii var. fulvum (Vickery) Connor \& Edgar, New Zealand J. Bot. 17: 332 (1979); Notodanthonia bipartita (Link) Veldk. var. fulva (Vickery) Veldk., Taxon 29: 296 (1980).

Type: New South Wales: Flemington, Vickery s.n., 31 Mar 1929 (NSW 1573!, holo, $\mathrm{K}$ !, iso).

Notodanthonia geniculata (J.M. Black) Zotov

Notodanthonia induta (Vickery) Veldk.

Notodanthonia laevis (Vickery) Zotov

Notodanthonia linkii (Kunth) Linder, comb. nov.

Basionym: Danthonia linkii Kunth, Enum. Pl. 1: 315 (1833); Rytidosperma linkii (Kunth) Connor \& Edgar, New Zealand J. Bot. 17: 332 (1979); Avena bipartita Link, Hort. Reg. Bot. Berol. 1: 113 (1827) non Danthonia bipartita F. Muell. (1859). Type: Not specified, but probably based on plant cultivated at Berlin. No type seen or noted by Vickery. Danthonia pallida var. subracemosa Bentham, Fl. Austral. 7: 593 (1878).

Type: Australia: MaCleay River, Beckler (K, lecto!), Warwick, Beckler(K!).

Notodanthonia mera (Connor \& Edgar) Linder, comb. nov.

Basionym: Rytidosperma merum Connor \& Edgar, New Zealand J. Bot. 17: 328 (1979). Type: New Zealand: Marlborough, Williams CHR 309413 (CHR, holo).

Notodanthonia monticola (Vickery) Veldk.

Notodanthonia occidentalis (Vickery) Veldk.

Notodanthonia oreophila (Linder $\mathcal{E}$ Walsh) Linder, comb. nov.

Basionym: Rytidosperma oreophilum Linder \& Walsh, Muelleria 8: 283 (1995).

Type: Australian Capital Territory: slopes of Mt Gingera, Bimberi Range, Pullen 3041, 24 Jan 1962 (CANB, holo!, NSW, L, A, K, NE, MEL, BO, iso)

Notodanthonia penicillata (Labill.) Zotov

Notodanthonia pilosa (R. Br.) Zotov

Notodanthonia popinensis (D. Morris) Linder, comb. nov.

Basionym: Danthonia popinensis D. Morris, Muelleria 7: 157 (1990).

Type: Tasmania: $0.5 \mathrm{~km} \mathrm{~N}$ of Kempton, Morris 8556 (HO 92651 holo!; AD, NSW! iso).

Notodanthonia racemosa (R. Br.) Zotov

Notodanthonia racemosa (R. Br.) Zotov var. obtusata (F. Muell.) Veldk. 
Notodanthonia remota (D. Morris) Linder, comb. nov.

Basionym: Danthonia remota D. Morris, Muelleria 7: 160 (1990).

Type:Tasmania: summit of Hibbs Pyramid, Buchanan 2878 (HO 91392, holo!)

Notodanthonia richardsonii (Cashmore) Veldk.

Notodanthonia setacea (R. Br.) Veldk.

Notodanthonia tenuior (Steud.) Conert

\section{Acknowledgements}

This research was funded by the ABRS (Australia) and the FRD (South Africa). HPL would like to thank the ANU and Australian National Herbarium CSIRO, Canberra, RBG Sydney, RBG Kew and LandCare, Christchurch for facilities and support. Thanks to Les Watson for encouragement and facilities, to Wendy Hitchcock for assistance, to Nigel Barker for access to his molecular data. Jef Veldkamp, Toby Kellogg, Surrey Jacobs, Mike Crisp and Bryan Simon made valuable comments on an earlier draft of the manuscript, Surrey Jacobs helped with fieldwork, and provided much assistance at the RBG Sydney.

\section{References}

Anderberg, A. and Tehler, A. (1990) Consensus trees, a necessity in taxonomic practice. Cladistics 6: 399-402.

Barker, N.P. (1994) External fruit morphology of southern African Arundineae (Arundinoideae: Poaceae). Bothalia 24: 55-66.

Barker, N.P. (1995) A molecular phylogeny of the subfamily Arundinoideae (Poaceae). Unpublished PhD thesis, University of Cape Town, South Africa.

Barker, N.P. and Ellis, R.P. (1991) A new species of Merxmuellera (Arundineae, Poaceae) from South Africa. Bothalia 21: 27-34.

Barker, N.P., Linder, H.P. and Harley, E.H. (1995) Polyphyly of the Arundinoideae (Poaceae): evidence from $r b c \mathrm{~L}$ sequence data. Syst. Bot. 20: 423-435.

Beadle, N.C.W., Evans, O.D. and Carolin, R.C. (1982) Flora of the Sydney Region, ed 3. (Reed: Wellington).

Bentham, G. (1878) Flora Australiensis, vol. 7. (Reeve: London)

Blake, S.T. (1972) Plinthanthesis and Danthonia and a review of the Australian species of Leptochloa (Gramineae). Contr. Queensland Herb. 14: 1-19.

Borgman, E. (1964) Anteil der Polyploiden in der Flora des Bismarckgebirges von Ostneuguinea. Zeitschr. Bot. 52: 118-172.

Bowden, W.M. and Senn, H.A. (1962) Chromosome numbers in 28 grass genera from South America. Canad. J. Bot. 40: 1115-1124.

Brock, R.D. and Brown, J.A.M. (1961) Cytotaxonomy of Australian Danthonia. Austral. J. Bot. 9: 62-91.

Calder, J.W. (1937) A cytological study of some New Zealand species and varieties of Danthonia. Bot. J. Linn. Soc. 51: 1-9.

Carpenter, J.M. (1988) Choosing among multiple equally parsimonious cladograms. Cladistics 4: 291-296.

Chase, A. (1918) Axillary cleistogenes in some American grasses. Amer. J. Bot. 5: 254-258.

Clay, K. (1983) Variation in the degree of cleistogamy within and among species of the grass Danthonia. Amer. J. Bot. 70: 835-843.

Clayton, W.D. and Renvoize, S.A. (1986) Genera Graminum. Grasses of the World (Her Majesty's Stationery Office: London). 
Conert, H.J. (1966) Dregeochloa, eine neue Gattung der Gramineen. Senckenberg. Biol. 47: 335-343.

Conert, H.J. (1970) Merxmuellera, eine neue Gattung der Gramineen. Senckenberg Biol. 51: 129-133.

Conert, H.J. (1971) The genus Danthonia in Africa. Mitt. Bot. Staatssamml. Muenchen 10: 299-308.

Conert, H.J. (1975) Ueber Danthonia domingensis Hackel et Pilger (Poaceae: Arundinoideae: Danthonieae). Senckenberg. Biol. 56: 293-313.

Conert, H.J. (1987). Current concepts in the systematics of the Arundinoideae. Pp. 239-250 in Soderstrom, T.R., Hilu, K.W., Campbell, C.S. and Barkworth, M.E., Grass Systematics and Evolution (Smithsonian Institution Press: Washington).

Conert H.J. and Türpe A.M. (1969) Karroochloa, eine neue Gattung de Gramineen (Poaceae, Arundinoideae: Danthonieae). Senckenberg. Biol. 50: 289-318.

Conert H.J. and Türpe A.M. (1974) Revision der Gattung Schismus (Poaceae: Arundiniodeae: Danthonieae). Abh. Senckenberg. Naturf. Ges. 532: 1-81.

Connor, H.E. (1991) Chionochloa Zotov (Gramineae) in New Zealand. New Zealand J. Bot. 29: 219282.

Connor, H.E. and Edgar, E. (1979) Rytidosperma Steudel (Notodanthonia Zotov) in New Zealand. New Zealand J. Bot. 17: 311-337.

Connor, H.E. and Edgar, E. (1981) Argument against rejection of Plinthanthesis Steud. (Prop. 520). Taxon 30: 657-658.

Dallwitz, M.J. (1980) A general system for coding taxonomic descriptions. Taxon 29: 41-46.

Dallwitz, M.J. and Paine, T.A. (1986) Users guide to the DELTA system - a general system for processing taxonomic descriptions. Third Edition. CSIRO Australian Division of Entomology Report 13.

Davidse, G. (1988) A revision of the genus Prionanthium (Poaceae: Arundinae). Bothalia 18: 143-153.

Davidse, G. and Pohl, R.W. (1972) Chromosome numbers, meiotic behavior, and notes on some grasses from Central America and the West Indies. Canad. J. Bot. 50: 1441-1452.

De Wet, J.M.J. (1956) Leaf anatomy and phylogeny in the tribe Danthonieae. Amer. J. Bot. 43: 175182.

De Wet, J.M.J. (1960) Leaf anatomy and morphology in South African species of Danthonia. Bothalia 7: 303-309.

Dobrenz, A.K. and Beetle, A.A. (1966) Cleistogenes in Danthonia. J. Range Managem. 19: 292-296.

Ellis, R.P. (1976) A procedure for standardising comparative leaf anatomy in the Poaceae. I. The leaf-blade as viewed in transverse section. Bothalia 12: 65-109.

Ellis, R.P. (1982). Leaf anatomy of the South African Danthonieae (Poaceae). VI. Merxmuellera arundinacea and M. cincta. Bothalia 14: 89-93.

Ellis, R.P. (1987) A review of comparative leaf blade anatomy in the systematics of the Poaceae: the past twenty-five years. Pp. 3-10 in Soderstrom, T.R., Hilu, K.W., Campbell, C.S. and Barkworth, M.E., Grass Systematics and Evolution. (Smithsonian Institution Press: Washington)

Farris, J.S. (1988) Hennig86 Reference. Published privately.

Gould, F.W. (1958) Chromosome numbers in southwestern grasses. Amer. J. Bot. 45: 757-768.

Hilu, K.W. and Esen, A. (1990) Prolamins in systematics of Poaceae subfam. Arundinoideae. Pl. Syst. Evol. 173: 57-70.

Hilu, K.W. and Wright, K. (1982) Systematics of Gramineae: a cluster analysis study. Taxon 31: 9-36.

Jacobs S.W.L. (1982) Comment on Proposal 520: Conservation of Notodanthonia Zotov (Gramineae). Taxon 31: 737-743.

Jacobs, S.W.L. (1988) Chionochloa howensis (Poaceae), a new species from Lord Howe Island. Telopea 3: $281-282$.

Jacobs, S.W.L. (1994) Poaceae . Pp. 410-656 in Harden, G.J. (ed.), Flora of New South Wales, vol. 4. (University of N.S.W. Press: Sydney).

Kellogg, E.A. and Campbell, C.S. (1987). Phylogenetic analysis of the Gramineae. Pp 310-322 in Soderstrom, T.R., Hilu, K.W., Campbell, C.S. and Barkworth, M.E., Grass Systematics and Evolution (Smithsonian Institution Press: Washington).

Leigh, J. (1991) Pastoral value and production from native grasses. Pp. 25-46 in Dowling, P.M. and Garden, D.L. (eds), Native Grass Workshop Proceedings (Australian Wool Corporation: Melbourne).

Linder, H.P. and Ellis, R.P. (1990) A revision of Pentaschistis (Arundineae: Poaceae). Contrib. Bolus Herb. 12: 1-124.

Lodge, G.M. and Groves, R.H. (1991) The domestication and agronomy of native grasses. Pp. 73-84 in Dowling, P.M. and Garden, D.L. (eds), Native Grass Workshop Proceedings (Australian Wool Corporation: Melbourne). 
Lodge, G.M. and Whalley, R.D.B. (1989) Native and natural pastures on the Northern Slopes and Tablelands of New South Wales: a review and annotated bibliography. New South Wales Agriculture and Fisheries Technical Bulletin 35: 1-49.

Maddison, W.P. and Maddison, D.R. (1992) MacClade. Analysis of phylogeny and character evolution (Sinauer: Massachusetts).

Mitchell, M. (1991) The status of native grasses in Victoria. Pp. 105-110 in Dowling, P.M. and Garden, D.L., Native Grass Workshop Proceedings (Australian Wool Corporation: Melbourne).

Nicora E.G. (1973) Novedades agrostologicas patagonicas. Darwiniana 18(1-2): 80-106.

Nixon, K.C. (1992) Clados, version 1.2. (The author: Ithaca, New York).

Nixon, K.C. (1993) Dada, version 0.86. (The author: Ithaca, New York).

Nixon, K.C. and Carpenter, J.M. (1993) On outgroups. Cladistics 9: 413-426.

Philipson M.N. and Connor H.E. (1984) Haustorial synergids in danthonioid grasses. Bot. Gaz. 145: 78-82.

Robards, G.E., Leigh, J.H. and Mulham, W.E. (1967) Selection of diet by sheep grazing semi-arid pastures on the Riverine Plain. 4. A grassland (Danthonia caespitosa) community. Austral. J. Exp. Agric. Anim. Husb. 7: 426-433.

Scott, A.W. and Whalley, R.D.B. (1982) The distribution and abundance of species of Danthonia DC on the New England Tablelands (Australia). Austral. J. Ecol. 7: 239-248.

Scott, A.W. and Whalley, R.D.B. (1984) The influence of intensive sheep grazing on genotypic differenction in Danthonia linkii, D. richardsonii and D. racemosa on the New England Tablelands. Austral. J. Ecol. 9: 419-429.

Simon, B.K. (1993) A Key to Australian Grasses, edition 2 (Queensland Department of Primary Industries: Brisbane).

Spies, J.J., Davidse, G. and Du Plessis, H. (1992) Cytogenetic studies in the genus Tribolium (Poaceae: Arundineae). Amer. J. Bot. 79: 689-700.

Stanley, T.D. and Ross, E.M. (1989) Flora of South-eastern Queensland, vol. 3. (Queensland Department of Primary Industry: Brisbane).

Swofford, D.L. (1993) Phylogenetic Analysis Using Parsimony (PAUP) vs. 3.1. (Illinois Natural History Survey: Champaign, Illinois).

Swofford, D.L. and Maddison, W.P. (1987) Reconstructing ancestral character states under Wagner parsimony. Math. Biosci. 87: 199-229.

Tolivia, D. and Tolivia, J. (1987) Fasga: a new phytochromatic for simultaneous staining of plant tissue. J. Microsc. 148: 113-117.

Tomlinson, K.L. (1985) Comparative anatomical studies in Danthonia sensu lato (Danthonieae: Poaceae). Aliso 11: 97-114.

Veldkamp, J.F. (1979) Poaceae. Pp. 1035-1224 in Van Royen, P., The Alpine Flora of New Guinea, Vol. 2. (J. Cramer: Vaduz).

Veldkamp, J.F. (1980) Conservation of Notodanthonia Zotov (Gramineae). Taxon 29: 293-298.

Veldkamp, J.F. (1993) Miscellaneous notes on southeast Asian Gramineae. VIII. New species in Danthonia. Blumea 38: 217-219.

Verboom, G.A., Linder, H.P. and Barker, N.P. (1994) Haustorial synergids: an important character in the systematics of danthonioid grasses (Arundinoideae: Poaceae)?. Amer. J. Bot. 81: 1601-1610.

Vickery J.W. (1956) A revision of the Australian species of Danthonia DC. Contr. New South Wales Natl. Herb. 2(3): 249-325.

Walsh, N.G. (1995) Poaceae. Pp. 526-543 in Walsh, N.G. and Entwistle, T.J., Flora of Victoria, vol. 2. (Royal Botanic Gardens: Melbourne).

Watson, L. and Dallwitz, M.J. (1992) The Grass Genera of the World (C.A.B. International: Cambridge).

Whalley, R.D.B. (1991) Native grasses in pastures in New South Wales. Pp. 95-104 in Dowling, P.M. and Garden, D.L. (eds), Native Grass Workshop Proceedings (Australian Wool Corporation: Melbourne).

Wilson, A.D. and Leigh, J.H. (1970) Comparisons of the productivity of sheep grazing natural pastures of the Riverine Plain. Austral. J. Exp. Agric. Anim. Husb. 10: 549-554.

Zotov V.D. (1963) Synopsis of the grass subfamily Arundinoideae in New Zealand. New Zealand J. Bot. 1: 78-136. 


\section{Appendix}

Characters used for phylogenetic analysis. Multistate characters are not additive (i.e. they are unordered) unless indicated to the contrary.

1. Innovation buds: intravaginal (0); extravaginal (1).

2. Leaf-blades: persistent (0); disarticulating (1).

Leaf-blades with distinct disarticulations are common in Chionochloa (Connor 1991, Linder in prep.), but are rare in the rest of the danthonioid grasses. A disarticulation line is best seen on carefully prepared herbarium specimens, in which the basal leaves have not been removed. Leaf-blade disarticulation is also found in a number of Rytidosperma species, and was used for the determination of New Zealand species of the genus (Connor \& Edgar 1979).

3. Inflorescence branches: more or less spreading (0); erect, inflorescence narrowly linear (1).

In most species, the inflorescence branches, at least at anthesis, are spreading. Erect inflorescence branches hug the central rhachis of the inflorescence, thus forming a linear inflorescence that approaches a raceme.

4. Cleistogenes: absent (0); present (1).

The presence of cleistogenes in the sheaths of the culm leaves has been reported and surveyed by Chase (1918), Dobrenz and Beetle (1966) and Clay (1983). This is restricted to Danthonia s.s., while Rytidosperma often has cleistogamous florets, distinct by the smaller anthers which dehisce while entangled within the stigmas of the unopened flowers (Vickery 1956).

5. Glumes: shorter than the florets (0); longer than the florets (1).

6. Callus: small (0); massive (1).

A massive callus is defined as constituting more than $70 \%$ of the combined callus and rhachilla length (Fig. 4: R, U).

7. Rhachilla length relative to the lemma: lemma/rhachilla $<5.8(0) ;>5.8(1)$.

This character is somewhat, but not completely, correlated to the previous character. This measures the degree of development of the rhachilla. Plotting the available measurement data shows a clear interval at ca. 5.8 (Fig. 4: Q-W).

8. Lemma lobes, excluding the setae: shorter than lemma (0); as long as lemma (1); longer than lemma (2)[additive].

These intervals in what is effectively a continuous character were chosen for convenience, as the states are easy to observe. A ratio was preferred over absolute measurements to avoid variation in spikelet size from influencing the result unduly.

9. Lemma lobe fusion to the central awn: absent (0); partial (1); complete (2)[additive].

The 'standard' lemma structure in the danthonioid grasses is a bilobed lemma, bearing an awn from the sinus (De Wet 1956). However, in four groups of probably unrelated taxa the lemma is entire, without lobes, the lemma apex acute or continuing into a short awn: Prionanthium (Davidse 1988), Tribolium (Linder and Davidse in prep.), Monostachya (Jacobs 1982) and some species of Pentaschistis (Linder \& Ellis 1990). We interpret the formation of this type of lemma as the fusion of the lemma lobes with the awn column. Intermediate conditions can be readily found: Schismus, especially S. pleuropogon (Conert \& Türpe 1974), and several species of Rytidosperma. In these taxa there is a partial fusion of the lemma lobes with the awn column. Associated with the fusion of the lemma lobes with the awn column is the loss of the awn limb (Fig. 4: A-G).

10. Lemma sinus: acute ( 0$)$; rounded (1).

11. Lemma lobe setae: longer than lobe (0); equal (1); shorter than lobe (2); absent (3)[additive]. 
12. Lemma indumentum on back: absent (0); scattered (1); tufted, at least top row (2) [nonadditive].

Abaxial lemma surface indumentum has been central in the controversies surrounding the generic delimitation within the Danthonia-Rytidosperma group of danthonioid species. We distinguish firstly between marginal hairs, which are usually visible as a long, continuous line along the lemma margins (Fig. 4: A), and abaxial lemma surface indumentum (Fig. 4: B-G). The latter is either scattered, generally in internerve rows (Fig. 4: E), or more or less tufted (Fig. 4: B-D, G). As noted by Jacobs (1982), there are intermediate forms. We regard the indumentum as tufted if tufts formed along the upper margin of the indumentum. At one extreme all indumentum is grouped into compact tufts, arranged into two transverse rows. These tufts are located between the nerves, resulting in 10 tufts if the row is complete. In several taxa only marginal (Fig. 4: D), or marginal and central (Fig. 4: B), tufts are present. The lower row is often diffuse, or may not be developed at all. When only the marginal tufts of the upper and lower row are present, this approaches the situation described as marginal hairs, but may be distinguished by the presence of two, rather than a single, marginal tuft (cf. Fig. 4: A, D). We made our observations on whole-mounts of the lemmas, using transmitted light - it may be more difficult to distinguish the different states using incident light on unstained material.

13. Lemma indumentum lower row: complete (0); only lateral tufts present (1).

14. Lemma lower indumentum row: tufted (0); diffuse (1).

15. Lemma indumentum below the upper row: forming a short felt $(0)$; longer and straggly (1).

16. Lemma indumentum upper row: complete (0); lateral and dorsal tufts (1); two lateral tufts (2); only lateral tufts (3)[nonadditive].

17. Lemma indumentum lateral strips: absent (0); present (1).

18. Upper lemma tufts: longer or equal to lobes (0); shorter than lobes (1).

19. Lemma awn: absent or very short (0); long (1).

Lemma awns are rarely totally absent, but there is a clear interval between awns which are generally shorter than the lobes (Fig. 4: E), as compared to well developed awns, much exceeding the lemma lobes. For the purposes of this character, the awns were not divided into the basal columns and the apical setae.

20. Lemma awn: longer than the lemma setae (0); shorter or as long as the setae (1).

21. Palea keels: not reaching apex (0); reaching apex (1).

Palea keels stopping short of the palea apex appears to be a synapomorphy of the Pentaschistis clade, and is associated with almost straight, glabrous or sparsely scabrid keels. In the rest of the danthonioid grasses the keels are strongly developed and ciliate, with margins incurved. These keels are sinuose, curving outwards in the middle, especially when the caryopsis is mature.

22. Palea length: = lemma (0); >> lemma (1).

23. Palea shape: narrow, less than $1 / 3$ as wide as long ( 0 ); broad, at least $1 / 3$ as wide as long (1).

24. Palea keels: glabrous to sparsely scabrid (0); densely scabrid or ciliate (1).

25. Palea keels: straight (0); curved (1).

26. Palea midcells: rectangular (0); inflated (1).

Generally the epidermal cells in the middle of the palea are rectangular, similar to the cells in other parts of the plants. However, in a few species of Rytidosperma the cells are inflated, and look quite distinct in surface view. 


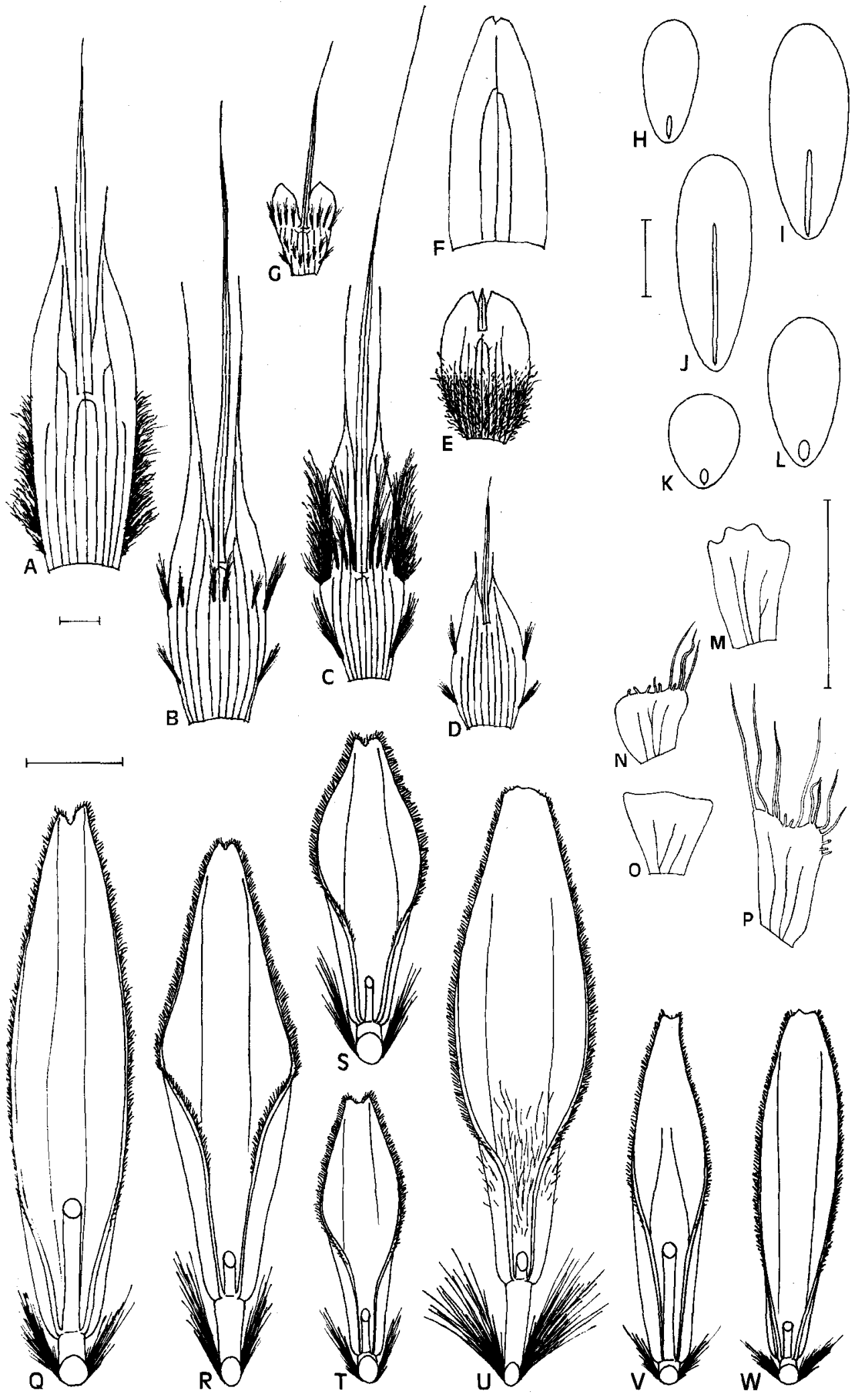




\section{Palea flaps: glabrous (0); hairy (1).}

The palea indumentum may be separated into two characters. The first character (27) describes the presence of long hairs between the palea margin and the keels. This indumentum is somewhat variable: in some species only a few hairs are present, while in others a dense indumentum may be formed. In very few species is the presence or absence of this indumentum variable. The second character (28, below) describes the presence of an indumentum between the keels. Almost invariably, this indumentum is located in the lower half of the palea, often as a small hairy patch (Fig. 4: U).

28. Hairs between palea keels: absent (0); scattered (1).

29. Lodicule apex: truncate (0); lobed (1); tri-lobed (2)[nonadditive].

Lodicule shape and indumentum was surveyed by Tomlinson (1985), and our observations are consistent with her results. Observations have to be made at anthesis, as lodicule shape changes from before to after anthesis. Care has to be taken with observations on lodicule indumentum, as the bristles and microhairs appear to be readily lost on worn lodicules. The density of the lodicule indumentum is somewhat variable between species, but not enough observations have been made to allow this character to be used (Fig. 4: M-P).

30. Lodicule microhairs: absent (0); present (1).

31. Lodicule bristles: absent (0); present (1).

32. Anthers: white to orange (0); red (1).

The three species of Joycea are readily distinguished by their large, red anthers. For neither colour nor size is there an absolute interval between Joycea and the other groups, but the combination appears to be unique. However, for a number of species there are no observations on the anther colour. This character needs a more comprehensive survey, which would have to be based on live plants.

\section{Hilum shape: linear (0); punctiform (1).}

The shape of the hilum was used by Zotov (1963) to delimit Rytidosperma, but his reliance on this character was critized by Blake (1972) and Jacobs (1982). It is a complex character (Fig. 4: H-L), composed of the actual shape, as well as the length of the hilum relative to the total caryopsis length. In general, in Rytidosperma the hilum is less than $40 \%$ of the length of the caryopsis. In Danthonia and Plinthanthesis the hilum is distinctly linear (Fig. 4: $\mathrm{I}, \mathrm{J}$ ), in most species of Rytidosperma it is ovate (Fig. 4: K, L), while in some species (especially in Karroochloa and Schismus (Conert and Türpe 1969, 1974)) it is punctiform. We coded the relatively short, ovate or punctiform hila as 'punctiform'. The hila of Joycea are intermediate in shape and length.

34. Leaf in transverse section: non nodular (0); nodular (1).

35 . Islands of colourless cells: absent (0); present (1).

These islands are situated in the chlorenchyma between the vascular bundles, and are variable in shape (Fig. 5: K). Care has to be taken to distinguish islands from holes in the chlorenchyma resulting from poor preservation or careless sectioning.

Fig. 4. (left) Variation in floret and caryopsis morphology. A-G: abaxial lemma surfaces, showing variation in indumentum patterns, venation patterns, and the development of awns and setae. A, Danthonia unispicata (Crampton 1999); B, Notodanthonia penicillata (Pullen 3034); C, N. alpicola (Craven 1633); D, Rytidosperma nitens (Moscal 1283); E, Plinthanthesis paradoxa (Austin 20); F, Notochloe microdon (Linder 5633); G, Karroochloa tenella (Compton 2882). H-K: outline of caryopsis, indicating the hilum shape and size. $H, R$. corinum (Druce CHR 402035); I, Notochloe microdon (Vickery NSW 18041); J, D. alpina (Richter 336); K, T. longifolia (McKee 9701); L, P. paradoxa (Ingwerson s.n.). M-P: lodicule morphology, indicating the general shape, from cuneate to three-lobed, venation patterns, and indumentum of micro- and macrohairs. $\mathbf{M}$, Notochloe microdon (Linder 5633); $\mathbf{N}, R$. nitens (Moscal 1283); O, D. unispicata (Crampton 1999); P, N. penicillata (Pullen 3034). Q-W: view of outside of palea, including callus and rhachilla internode. $\mathbf{Q}$, Notochloe microdon (Linder 5633); $\mathbf{R}, N$. penicillata (Pullen 3034); S, R. nitens (Moscal 1283); T, R. thomsonii (MacMillan p567); U, N. tenuior (Linder 5587); V, P. paradoxa (Austin 20); W, D. unispicata (Crampton 1999). Scale bar $=1 \mathrm{~mm}$. 
36. Metaxylem vessels: small (0); large (1).

Metaxylem vessels are coded as small if they are less than $1 / 5$ of the diameter of the vascular bundles. Variation in the relative size of the metaxylem vessels is continuous: this particular interval was chosen to maximise the informativeness of the character.

37. Bulliform cells: absent (Fig. 5: A, D, K) (0); flanking midvein (Fig. 5: G) (1); ubiquitous (2)[additive].

38. Abaxial epidermal thickening: absent (Fig. 5: I, L) (0); slight (1); extreme (Fig. 5: C) (2)[additive].

39. Sclerenchyma cap: small (0); large (1).

A sclerenchyma cap appears to be consistently present in all danthonioid species. However, the degree of development of the cap varies: large caps are generally wider than the costal regions and, when well developed, are visible on the leaf margin as a narrow hyaline strip. This character is not visible where a continuous subepidermal sclerenchyma layer is present, but this is very rare in the Rytidosperma group.

40. Number of primary vascular bundles (from margin to and including midvein): $1-3(0)$; $4-6(1)$.

This counts as the midvein and the number of primary vascular bundles in half the leaf. It is partially a measure of the width of the leaf.

41. Macrohairs: absent (0); present (Fig. 5: H) (1).

42. Abaxial silica: costal similar to intercostal silica (Fig. 5: C) (0); costal different from intercostal silica (1).

43. Abaxial costal silica: saddle shaped (Fig. 5: I) (0); cork silica pairs (Fig. 5: C) (1).

44. Intercostal silica bodies: rounded (0); elongated/kidney shaped (1).

45. Abaxial microhair apical cell (a) to basal cell (b) length ratio: $a / b \geq 2(0)$; $1 \leq \mathrm{a} / \mathrm{b}<2$ (Fig. 5: I, L) (1); $\mathrm{a} / \mathrm{b}<1$ (2)[additive].

46. Abaxial stomata: absent (0); present (Fig. 5: I) (1).

47. Abaxial prickles: absent (0); present (Fig. 5: H, I, K) (1).

48. Adaxial papillae: absent (0); present (1).

Adaxial papillae (Fig. 5: B, E) are commonly present and variable in shape and size in Chionochloa (Linder in prep). However, it is only sporadically present in Rytidosperma, and not variable in shape. Papillae also occur sporadically in several other genera of the danthonioid grasses.

49. Chromosome number: diploid (0); tetraploid (1); hexaploid (2)[additive].

This is based on the chromosome counts of Brock and Brown (1961), Bowden and Senn (1962), Gould (1958), Calder (1937) and Spies et al. (1992). All numbers are based on $x=6$. Taxa were scored as diploid if the chromosome numbers are in multiples of 12 , tetraploid if in multiples of 24, and hexaploid if in multiples of 36 . This coding system was employed to detect different 'basal' numbers for different genera of danthonioid grasses. Unfortunately, several critical genera (e.g. Plinthanthesis) are still unknown cytologically. The count of $n=10$ for Rytidosperma oreoboloides (Borgman 1964) was ignored, as it has not been corroborated.

Fig. 5. (right) Leaf anatomy of four species, displaying the major variation in the study group. A, B, D, E, G, H, J, K: transverse sections; C, F, I and K: adaxial epidermis. Sclerenchyma indicated by black shading. A-C: Rytidosperma montis-wilhelmii (Mclean \& Wade 7285), note the silica bodies are all round, with no differentiation between the costal and intercostal zones. D-F: R. pauciflora (Linder 5688), note small metaxylem vessels. G-I: Notodanthonia pilosa (Linder 5571), note the macrohairs, unfurrowed leaves, numerous stomata. J-L: Plinthanthesis rodwayi (Linder 5623), note the islands of colourless cells between the vascular bundles, and the rounded ridges on the leaves. Scale bar $=0.1$ $\mathrm{mm}$, except for $\mathrm{G}$ and $\mathrm{J}$, where it is $1 \mathrm{~mm}$. 


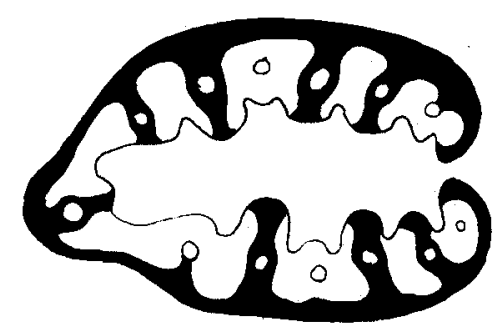

A

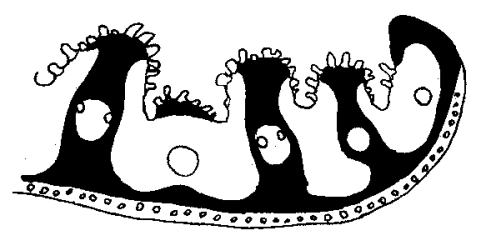

B

सRم:

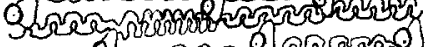
ret त⿵ ת.

C
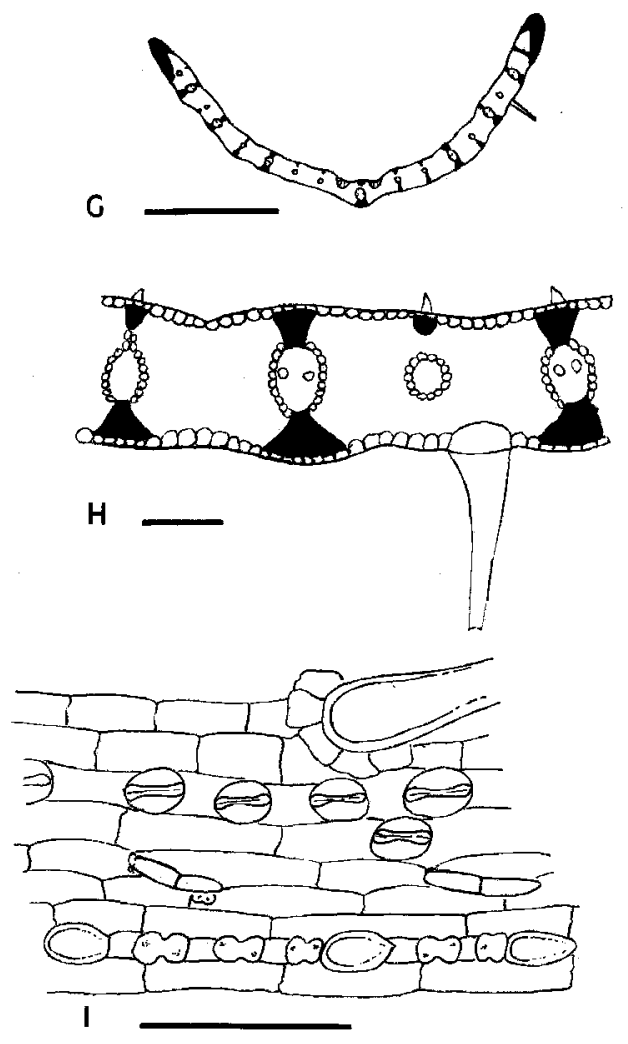

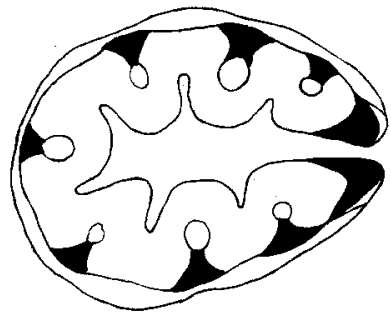

D

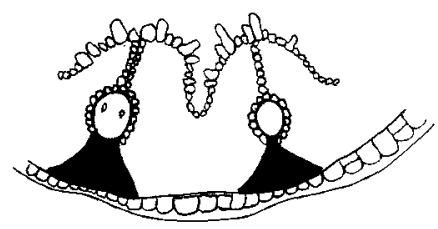

E

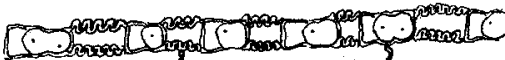

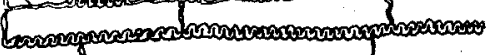

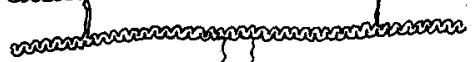

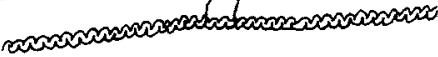

$\mathbf{F}$
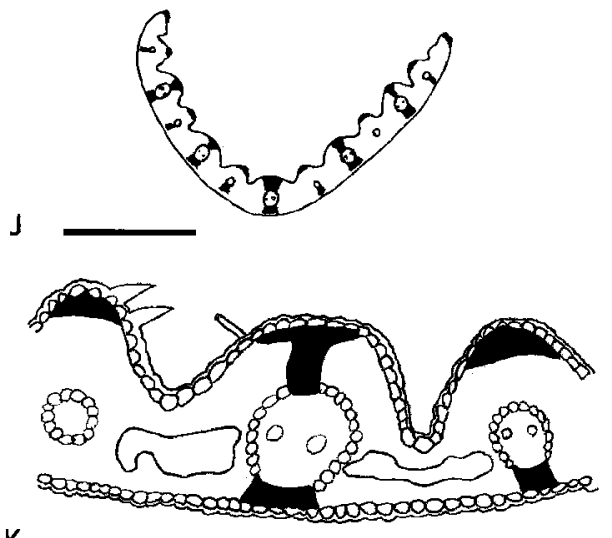
K

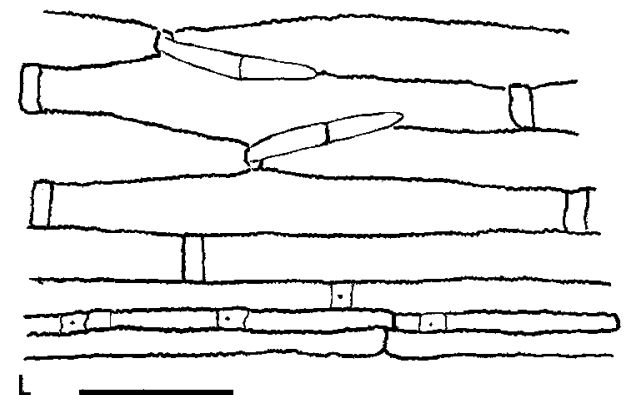


Table 1. Distribution of character states among the taxa. Unknown characters are indicated by '?', inapplicable characters by ' - ' and polymorphic characters by '*'.

\begin{tabular}{|c|c|c|c|c|c|c|c|c|c|c|}
\hline & 5 & 10 & 15 & 20 & 25 & 30 & 35 & 40 & 45 & \\
\hline Danthonia alpina & 00011 & 01000 & $10---$ & $-1-00$ & 10011 & $? 00 ? ?$ & $? 0000$ & 12101 & 01012 & 0002 \\
\hline D. cachymeriana & 1001 & 00000 & $2200-$ & 00110 & 10001 & $? 00 ? ?$ & $? 0010$ & 11000 & $110-2$ & $100 ?$ \\
\hline D. californica & $0001 *$ & 01000 & $00-11$ & $-1-10$ & 10011 & $? 0000$ & 00000 & 12110 & 01011 & 1002 \\
\hline D. schneideri & $0 * 001$ & 00000 & $* 200-$ & 00110 & 10001 & ????? & $? 0010$ & 11100 & 11002 & $100 ?$ \\
\hline D. sericea & 00011 & 00000 & *1-11 & $-1-10$ & 10111 & $-00 ? ?$ & $? 0010$ & $1 ? 110$ & 11001 & $010 ?$ \\
\hline D. unispicata & 00011 & 01010 & $20 \ldots$ & $-1-10$ & 10011 & $? 0000$ & 00010 & & 11012 & 0102 \\
\hline Joycea clelandii & 00001 & 00000 & $21 ? 11$ & $? 0110$ & 11011 & 00011 & 11000 & 11000 & 01011 & 0001 \\
\hline J. pallida & $0000^{*}$ & 00100 & $21-11$ & $-0-10$ & 11011 & 01111 & $11 * 00$ & 11200 & 01001 & 1101 \\
\hline Karroochloa curva & 00001 & $0 ? 101$ & $2200-$ & $01-10$ & 11011 & 01101 & 10100 & 12100 & 01011 & 1000 \\
\hline K. tenella & 00001 & 00101 & $3200-$ & 00010 & $1-111$ & 00001 & -0100 & 12000 & 11011 & 1000 \\
\hline Notodanthonia alpicola & 00001 & 00100 & $0210-$ & 00010 & 11011 & 00101 & 10100 & 11111 & 11010 & 1001 \\
\hline N. auriculata & 00001 & 11100 & $0200-$ & 00110 & 10111 & -1101 & 10100 & 12210 & 11011 & 1001 \\
\hline N. biannularis & 00001 & 11200 & 22011 & 00010 & 10111 & $? 1101$ & 10100 & 11111 & $010^{*}-$ & $100 ?$ \\
\hline N. caespitosa & 00001 & 11200 & $? 200-$ & 00110 & $? 10 ? 1$ & $? 10 ? 1$ & 10100 & 11111 & 11011 & 1001 \\
\hline N. carphoides & 00001 & 11000 & 02211 & 00011 & 11111 & $? 1101$ & 10100 & 01110 & 11011 & 1001 \\
\hline N. clavata & 10101 & 11200 & $1200-$ & 10110 & 10011 & $? * 001$ & $10 ? 10$ & 12111 & 11001 & $100 ?$ \\
\hline N. diemenica & 00001 & 10100 & $2200-$ & 00010 & 11111 & $? * 011$ & 10100 & 11010 & $01 ? 0 ?$ & $000 ?$ \\
\hline N. duttoniana & 00001 & 11100 & $0200-$ & 00110 & & 00001 & 10101 & 11111 & 01010 & 100.1 \\
\hline N. eriantha & 00001 & 11100 & $0200-$ & $00 * 10$ & 10111 & 11001 & 10100 & 01110 & 11011 & $100^{*}$ \\
\hline N. fulva & 00001 & 11200 & 22011 & 00110 & 11011 & 01101 & 10100 & 100 & 01011 & $100 *$ \\
\hline N. geniculata & 00001 & 11200 & 22011 & 00111 & 11111 & $? 1101$ & 10100 & 01110 & 11011 & 1001 \\
\hline N. induta & 00001 & 11200 & $220 ? 1$ & 00110 & 11011 & $? 1 * 01$ & 10100 & 12110 & 11011 & 1001 \\
\hline N. laevis & 00001 & 11100 & $* 210$ & 00110 & 11111 & $? 0001$ & 10110 & 11201 & 11011 & 1001 \\
\hline N. linkii & 00001 & 11200 & 22011 & 00010 & 11011 & 01101 & 10100 & 12110 & $1 ? ? ? ?$ & 0001 \\
\hline N. mera & 10001 & 11000 & $0210-$ & 20110 & 11011 & -0001 & & 010 & 11011 & $100 ?$ \\
\hline N. monticola & 00001 & 11200 & $2200-$ & 00111 & 11111 & $? 1101$ & 10100 & 00110 & 11011 & 1001 \\
\hline N. penicillata & 10101 & 11200 & $2200-$ & 10110 & 11011 & 00001 & 10100 & 11111 & 01011 & 1001 \\
\hline N. pilosa & 00001 & 11100 & $0200-$ & 10110 & 10011 & 00001 & 10110 & 11111 & 11011 & 1001 \\
\hline N. racemosa & 10100 & 11100 & $2200-$ & 10110 & 11011 & $? 0001$ & 10100 & 02010 & $* 1011$ & 1001 \\
\hline N. setacea & 00001 & 11000 & $1200-$ & 00110 & 11111 & $? 1001$ & 10100 & 01100 & 11011 & 1001 \\
\hline Notochloe microdon & 10000 & 01020 & $30---$ & $-0-0-$ & 11011 & 00010 & 10001 & 11100 & 01011 & $100 ?$ \\
\hline Plinthanthesis paradoxa & 00000 & 00010 & $31-10$ & $-0-0-$ & 11011 & 01100 & 00001 & 10100 & 01011 & $100 ?$ \\
\hline P. rodwayi & 00001 & 00010 & $31-10$ & $-0-0-$ & 11011 & 01100 & $00 ? 01$ & 12201 & 01011 & $000 ?$ \\
\hline Pentaschistis curvifolia & 00001 & 01000 & $01-11$ & $-0-10$ & & 00100 & 00000 & 12101 & 00110 & 0000 \\
\hline Rytidosperma australe & 01000 & 00020 & $30---$ & $-0-0-$ & 10011 & 10000 & 00100 & 00000 & 01000 & $001 ?$ \\
\hline R. buchananii & $0100 ?$ & 00010 & $2200-$ & 00110 & $1 ? 011$ & 10001 & $10 ? 00$ & 00200 & 01001 & $000 *$ \\
\hline R. corinum & 01001 & 00100 & $0200-$ & 10110 & 11011 & 00001 & $? 0100$ & 00100 & 010?- & $001 ?$ \\
\hline
\end{tabular}




\begin{tabular}{|c|c|c|c|c|c|c|c|c|c|c|}
\hline & 5 & 10 & 15 & 20 & 25 & 30 & 35 & 40 & 45 & \\
\hline R. craigii & 01000 & 00020 & $3210-$ & 20110 & 11011 & 00001 & $10 ? 00$ & 00210 & $1110-$ & $001 ?$ \\
\hline R. dimidiatum & 01001 & 01000 & $1200-$ & 00110 & 11011 & 10001 & 10100 & 01100 & 11010 & $100 ?$ \\
\hline R. exiguum & $1000 *$ & 00020 & $3210-$ & $2010-$ & 10011 & 01011 & 10100 & 00200 & $010 ? 1$ & 101 \\
\hline R. fortunae-hibernae & 00001 & 00100 & $2210-$ & 00010 & 11011 & $? 1001$ & 10100 & 00100 & 11011 & $000 ?$ \\
\hline R. maculatum & 01001 & 00000 & $2200-$ & 00110 & 11011 & 01001 & $10 ? 00$ & 00100 & $110 ? 1$ & $100 ?$ \\
\hline R. montis-wilhelmii & 01000 & 00010 & $? 210-$ & 20110 & $? 10 ? 1$ & $? 0001$ & $? 0 ? 00$ & 00201 & $0010-$ & $001 ?$ \\
\hline R. nardifolium & 01001 & 00010 & $0210-$ & 20110 & 11011 & $? 0001$ & ${ }^{*} 0 ? 00$ & 10200 & $0010-$ & $001 ?$ \\
\hline R. nitens & $0100 *$ & 00010 & $2210-$ & 20110 & 10111 & 10001 & 10100 & 01100 & 01010 & 100 \\
\hline R. nivicolum & $100^{*}$ & 00010 & *210- & 10110 & 11111 & $? 10 * 1$ & & & $0110-$ & 0011 \\
\hline R. nudiflorum & $100^{*}$ & 00110 & $1210-$ & 20110 & 11011 & $? 1101$ & 10100 & $002 ? 1$ & $011--$ & $00 ? 1$ \\
\hline R. nudum & 01001 & 00010 & $3210-$ & 00110 & 11011 & $-{ }^{*} 001$ & $00 ? 00$ & 00110 & 01001 & $001 ?$ \\
\hline R. oreoboloides & 01000 & 00020 & $3210-$ & 2010 & 11011 & $? 0001$ & $* 0100$ & 00200 & $0010-$ & 0011 \\
\hline R. pauciflorum & 01001 & 00100 & $2200-$ & 00010 & 11011 & 10021 & 10100 & 00200 & $0100-$ & $001 ?$ \\
\hline R. petrosum & 1001 & 00200 & $2200-$ & 10110 & 11011 & 01001 & $10 ? 00$ & & $010 ?-$ & $101 ?$ \\
\hline R. pictum & 0001 & 00100 & $1200-$ & 00010 & 11011 & $? 0101$ & $10 ? 00$ & & $1100 ?$ & $100 ?$ \\
\hline R. pulchrum & 1001 & 00000 & $2200-$ & 00010 & & $0000 ?$ & 10100 & & & $001 ?$ \\
\hline R. pumilum & $0100^{*}$ & $0 ? 020$ & $3200-$ & $0010-$ & 10011 & $? 0 ? 1 ?$ & $00 ? 00$ & 00200 & $00 ? ?-$ & $001 ?$ \\
\hline R. setifolium & 1001 & 00100 & $2200-$ & 00010 & 11001 & $? 11 ? ?$ & $? 01 ? 0$ & 00100 & $01 ?-?$ & 0011 \\
\hline R. tenue & 00001 & 11200 & 2200 & 00010 & 10011 & 01101 & $10 * 00$ & 11101 & 01010 & $100^{*}$ \\
\hline R. thomsonii & $0100 *$ & 00020 & $2210-$ & 20110 & 11011 & 00000 & $10 ? 00$ & 00200 & 00111 & $000 ?$ \\
\hline R. vestitum & 00001 & 00200 & $2200-$ & 00010 & 11011 & $? 1111$ & 10100 & 00200 & 01101 & $001 ?$ \\
\hline R. vickeryae & 00000 & 00010 & $32-0-$ & & & & & & $0100-$ & 0011 \\
\hline R. virescens & 00001 & 00100 & $2200-$ & & 11011 & $0100 ?$ & 10100 & 10110 & $1000 ?$ & $100 ?$ \\
\hline R. viride & 01001 & 00200 & $2200-$ & 00010 & 11011 & $? 1101$ & 10100 & 10100 & 00011 & $101 ?$ \\
\hline Schismus barbatus & 00000 & 00010 & $31-11$ & $-1-0-$ & $1 * 101$ & $00 * 01$ & $101 ? 0$ & 10100 & 01011 & * 100 \\
\hline 5. inermis & 00000 & 00010 & $31---$ & $-1-0$ & 10111 & 01101 & 10100 & 10100 & $0101-$ & 0100 \\
\hline Thonandia gracilis & 10001 & 00200 & $? 2-10$ & 00010 & $? 10 ? 1$ & $? 010 ?$ & $10 ? 00$ & 12100 & 01011 & 1001 \\
\hline T. longifolia & 00001 & 00200 & $12-10$ & & & & & & & 0001 \\
\hline T. nigricans & $1000 ?$ & 00200 & $22-10$ & 00010 & & 00011 & $10 ? 00$ & 12101 & 01011 & 1001 \\
\hline T. unarede & 10001 & 00200 & $22-0-$ & 00110 & 11011 & 01011 & 10100 & 11110 & $110 ? 0$ & $100 ?$ \\
\hline Tribolium hispidum & 00001 & 01020 & 30 & $-1-0-$ & 10001 & ?*101 & $* 0100$ & 10100 & 11100 & 1000 \\
\hline T. pusilla & $0000 *$ & $0 ? 020$ & $30---$ & $-1-10$ & 11001 & -1000 & $00 ? 00$ & 12000 & $111 ? 0$ & $100 ?$ \\
\hline T. uniolae & 10000 & 01020 & $30-11$ & $-1-0-$ & 10001 & $? 1001$ & 10100 & $12 * 00$ & $* 1 * * 0$ & 1001 \\
\hline
\end{tabular}

